\title{
Plant bioactives for ruminant health and productivity
}

\author{
Simone Rochfort ${ }^{\mathrm{a}, *}$, Anthony J Parker ${ }^{\mathrm{b}}$, Frank R. Dunshea ${ }^{\mathrm{c}}$ \\ a Environmental Health and Chemistry, Department of Primary Industries, Primary Industries Research Victoria - Werribee Centre 3030, Victoria, Australia \\ ${ }^{\mathrm{b}}$ Ridley AgriProducts Pty Ltd., 70-80 Bald Hill Road, Pakenham 3810, Victoria, Australia \\ ${ }^{\mathrm{c}}$ Land and Food Resources, The University of Melbourne, Parkville 3052, Victoria, Australia
}

Received 23 March 2007; received in revised form 31 July 2007

Available online 4 October 2007

\begin{abstract}
Plants have been used throughout history for their medicinal properties. This use has often focused on human health but plants have also been, and still are, applied in ethnoveterinary practice and animal health management.

In recent times, the use of synthetic chemicals has become prevalent. Public awareness of the potential environmental and health risks associated with heavy chemical use has also increased. This has put pressure on regulatory bodies to reduce the use of chemicals in agriculture. The most striking example is the 2006 banning of antibiotics in animal feed by the European Union. Moves such as this have increased the drive to find alternatives to synthetic chemicals and research has again turned to the use of plant bioactives as a means of improving animal health.

Current scientific evidence suggests there is significant potential to use plants to enhance animal health in general and that of ruminants (cattle, deer, sheep, etc.) in particular. Active areas of research for plant bioactives (particularly saponin and tannin containing plants) include reproductive efficiency, milk and meat quality improvement, foam production/bloat control and methane production. Nematode control is also a significant area of research and the evidence suggests a much broader range of phytochemicals may be effective. This review presents a summary of the literature and examines international research efforts towards the development of plant bioactives for animal health.
\end{abstract}

(C) 2007 Elsevier Ltd. All rights reserved.

Keywords: Ruminant; Anthelmintic; Methanogensis; Bloat control; Saponin; Tannin; Animal health

\section{Contents}

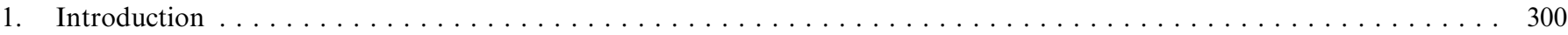

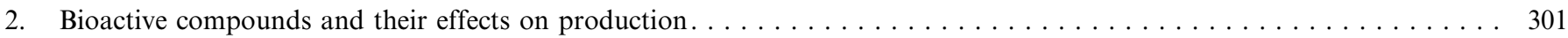

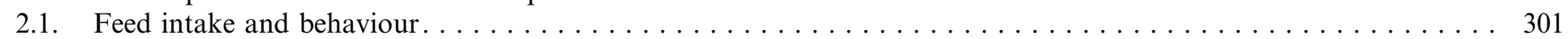

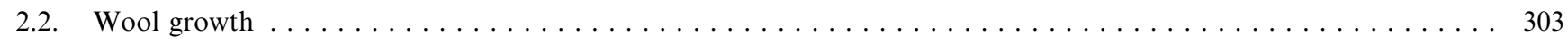

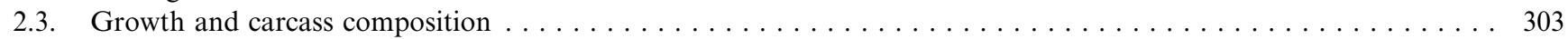

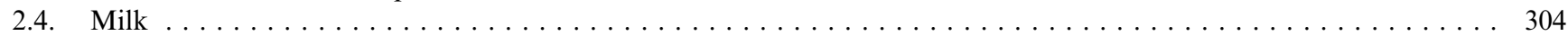

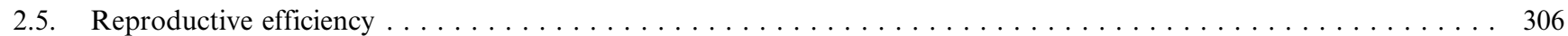

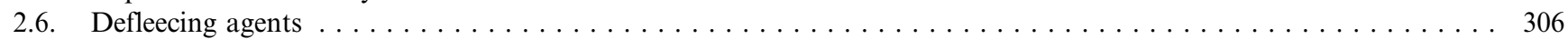

3. Bioactive compounds and their effects on rumen environment $\ldots \ldots \ldots \ldots$

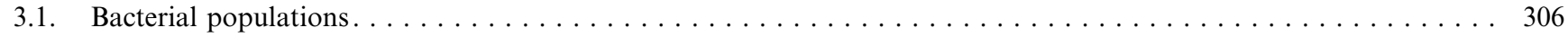

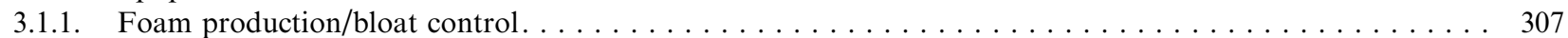

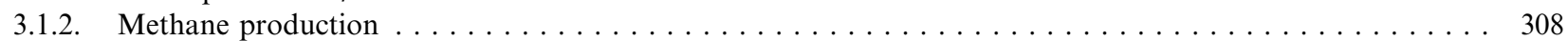

\footnotetext{
* Corresponding author. Tel.: +61 397428704.

E-mail address: simone.rochfort@dpi.vic.gov.au (S. Rochfort).
} 


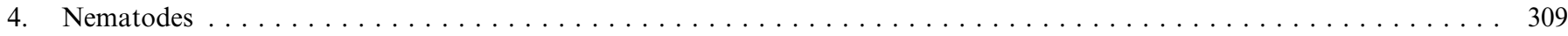

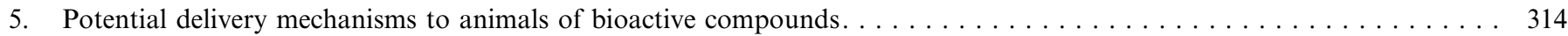

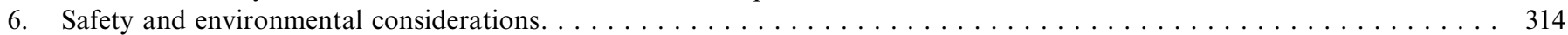

7. Social drivers for the replacement of antibiotics in animal feed $\ldots \ldots \ldots \ldots$

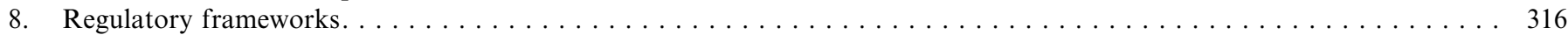

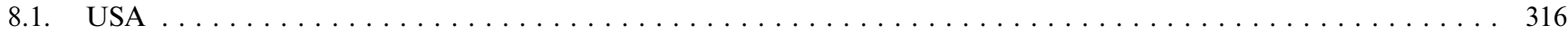

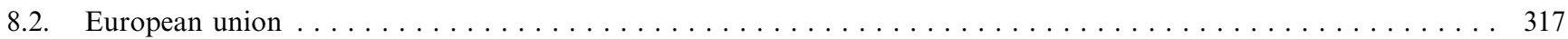

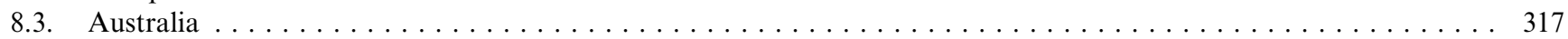

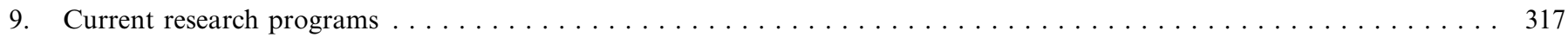

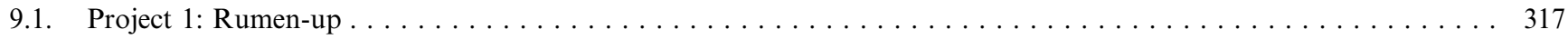

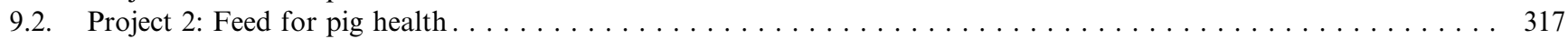

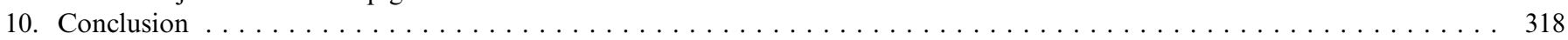

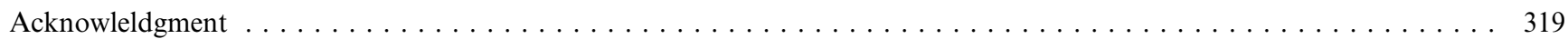

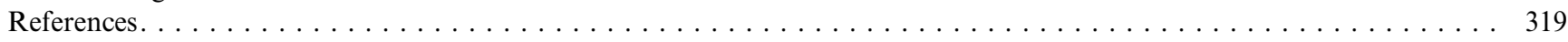

\section{Introduction}

Mainstream animal production relies heavily on the use of pharmaceuticals. Many of these products are developed through research and development for human pharmaceutics. Natural products are an important source of new drugs and drug leads in the pharmaceutical industry. For the animal market many of the currently used antimicrobial, feed additive antibacterial, endectocide and anticoccidial drugs are either natural products or synthetics based on natural products (Ruddock, 2000). The majority of these natural products are produced from the fermentation broth of microorganisms, though plants have also been an important source of bioactives. There is increasing public concern regarding the use of pharmaceuticals in the animal industry. Much of this has been as a result of the emergence of drug resistance. A particular area of criticism has been in the use of antibiotics as growth promoters and the associated risk of developing antibiotic resistance in human pathogens (Barton, 2000). This is not a new issue and in 1969 the Swann report resulted in the withdrawal of $\beta$-lactams from feed in the UK (Ruddock, 2000). However, this increasing trend has led to a closer examination of plants for animal health. In Western culture, plants in the livestock industry have largely been considered as a source of nutrition or potential source of toxicity. Increasingly there is the realization that plants may offer non-nutrient performance enhancing factors that benefit animal production (Greathead, 2003). This realization has resulted in increased research, with the number of publications in this area increasing over the last $8-10$ years. The research area is of sufficient significance to warrant focus in the journal 'Animal Feed Science and Technology'. In 2005, issues one and two were dedicated to "Phytochemicals in Livestock Production Systems". Specific programs to investigate the use of plants for animals have also been developed. For example, the banning of feed antibiotics by 2006 in the European Union (EU) prompted investment in the Framework 6 REPLACE program which, aims to screen 500 plants for a range of activities, including antibacterial, nematocidal and immune stimulating effects (EU-Replace, 2006).

This paper reviews the use of plants or their extracts to enhance ruminant health. Evidence from various sources, including in vitro and in vivo experiments and ethno-veterinary studies is discussed. Not considered here are potential natural products derived from organisms other than plants. That is, bacteria and fungi are not covered in this review. There is already substantial evidence for the success of microbes in this area, and indeed, many of the antibiotics and helminthics used today are either microbial natural products or derivatives there of (e.g. avermectins and milbemycins from Streptomyceses species). Live organisms such as fungi have also been used for in situ nematode control. The commercially available DiTera contains the fungus Myrothecium spp whilst Paecil, which contains Paecilomyces lilacinus, has been used as a soil drench, the fungus being a nematode egg parasite (Ghisalberti, 2002). Potential biological mechanisms of control, such as this, will not be considered further in this review.

It is worth noting that plant bioactives are still an underexplored area of research and in many cases although biological activity has been observed, the natural phytochemicals responsible for the activity have not been identified. For example, a compilation of plants with nematocidal activity produced in 1997 contained 150 entries and for most the active agents have yet to be identified (Ghisalberti, 2002).

Animal pharmaceutics are often derived from studies for human medications and for these studies ruminants are usually not the focus of bioactive investigation. There have been an extraordinary number of plant metabolites with antibiotic activity reported. A literature search using the terms "antibiotics from plants", yielded over 5000 references. The majority of the compounds/plants identified in these articles will never have been specifically tested in ruminants. Indeed, adding the words "and studies in ruminants" reduces the number of references to 30 , and only a 
small proportion of these is relevant to the topic. There is no doubt that past knowledge and the literature is a useful guide for developing therapeutic approaches. However, even a cursory search of the literature reveals a daunting amount of information on plant metabolites but with relatively little work done for ruminant health. Table 1 presents a summary of the results of a literature search that examines specific classes of plant compounds. Plant metabolites were searched based on structure type (terpene, alkaloid, lipid, carbohydrate, aromatic, saponin, tannin) and then each class examined for reports of bioactivity, specifically antibiotic or anthelmintic activity. The results were further refined to focus on ruminant specific research. There are some limitations and redundancy in this data but it highlights the large number of publications discussing plant metabolites and their antibiotic and anthelmintic activities. Manual inspection of each refined reference further reveals that some of the articles are 'false positives' in that they do not necessarily focus on ruminant health (e.g. some mention bovine serum albumin in the abstract). Fig. 1 portrays this information visually and shows the areas of greatest study in terms of ruminants. Indeed, for ruminants, there is very little literature that focuses on

Table 1

Plant compounds and associated data

\begin{tabular}{lrrrr}
\hline Compound class & \multicolumn{4}{l}{ Number of references $^{\mathrm{a}}$} \\
\cline { 2 - 5 } & Total & Bioactive & Ruminant & Relevant \\
\hline Terpene & 6410 & 339 & 53 & 19 \\
Alkaloid & 15,195 & 617 & 9 & 3 \\
Lipid & 37,351 & 1338 & 41 & 19 \\
Carbohydrate & 31,137 & 582 & 22 & 6 \\
Aromatic & 11,786 & 447 & 12 & 2 \\
Saponin & 3464 & 309 & 12 & 8 \\
Tannin & 3275 & 125 & 15 & 12 \\
Total & 108,618 & 3757 & 164 & 69
\end{tabular}

${ }^{\text {a }}$ Searched on 29/9/06 using Scifinder. Each chemical class was searched as a key word independently and refined using the phrase "bioactive or antimicrobial or anthelmintic or antibiotic". Specific references were identified when refined using the phrase "ruminants or cow or deer or sheep". Relevant references were identified by manual inspection. plants as alternatives to antibiotics. In ruminant health the focus has been on bioactive effect of plants on ruminal flora rather than on specific pathogenic bacteria. This is perhaps understandable, since many of the desirable effects of antibiotics used as growth stimulants act through modification of the ruminal microbe population.

Delivery of bioactives is an important consideration. The form the bioactive presented to the animal will affect not only bioavailability but also cost of delivery. Options for delivery range from growing the plant in field, through to application as hay, to dosing with either pure material or concentrated plant extract. In many ways the simplest of these is infield plant production, however there are numerous considerations as highlighted in a recent review, "Arguably the simplest method of delivering bioactive plant secondary metabolites to animals outdoors would be to grow the relevant plants in a field and then let the animals graze them in a controlled manner, assuming they are palatable" (Greathead, 2003). However, the authors note that the efficiency of such a method is doubtful, since despite the crude control of intake via controlled grazing, there would be no control on dosage due to the interplant variation in secondary plant metabolite (SPM) content. Methods of uniformly stressing plant crops to ensure uniformity of SPM and perhaps even invoking the production of certain metabolites could be investigated (Greathead, 2003). Plants are essential for ruminant nutrition but offer benefits beyond basic nutrition. Judicious use of specific bioactive plants has the potential to impact on almost every aspect of ruminant production.

\section{Bioactive compounds and their effects on production}

\subsection{Feed intake and behaviour}

Feed intake and animal-feeding behaviour is governed by many factors including availability, palatability and feed back mechanisms. Tannin containing plants have been the subject of significant research effort. The recent review by Mueller-Harvey (2006) is an excellent summary of this

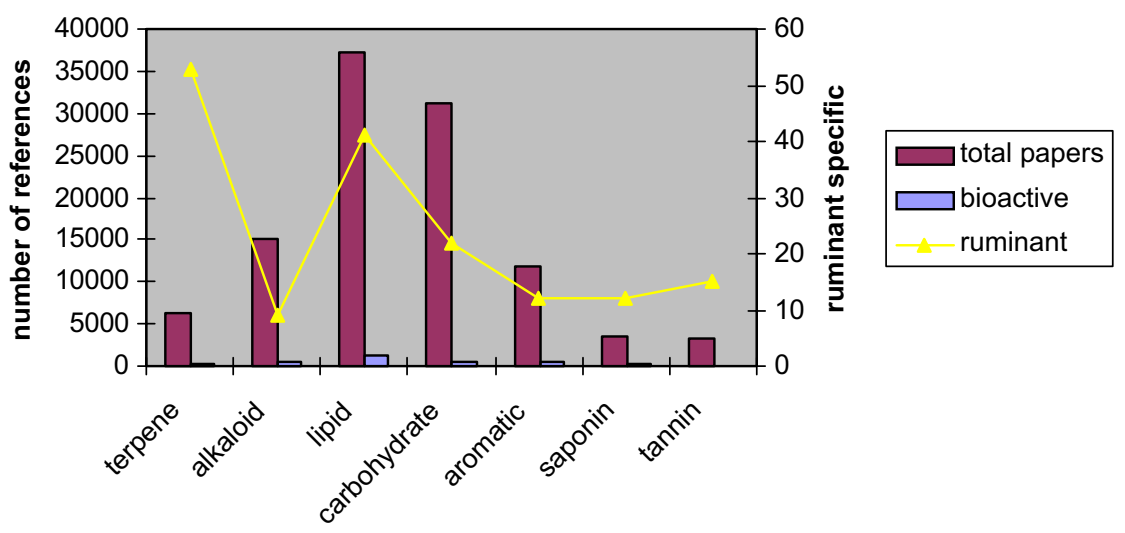

Fig. 1. Literature analysis of plant compounds for ruminant health. 
work. Condensed tannins may be beneficial in the diet but at certain levels begin to affect feed intake. This level varies considerably, depending on the chemical nature of tannin and the animal species studied. The evidence is mixed, sometimes conflicting and often difficult to interpret in an objective manner since the actual tannin composition is not always well described. An additional complicating factor is the different physiological responses to tannin amongst ruminants. For example, deer saliva has tanninbinding proteins that are not found in sheep. The two animals also metabolise tannins of different structure classes in a different manner. In both deer and sheep, hydrolysable tannin is broken down shortly after consumption and there are no diminished protein absorption effects. However, condensed tannins (CT) were recovered almost entirely from deer faeces, but only $60 \%$ recovered from sheep faeces, suggesting some absorption. Importantly gallotannins from different sources also had different effects on protein digestibility suggesting that both gross and subtle differences in tannin chemistry must be considered when assess- ing the effect of tannin on ruminants (Robbins et al., 1991; Hagerman et al., 1992). Typical tannins are depicted in Fig. 2. The gallotannin (1) and ellagitannin (2) are members of the so-called hydrolysable tannins, whilst the proanthocyandin, (3), is one member of the condensed tannin family.

Condensed tannins (CT) present in a number of plant species may inhibit the activity of ruminal microorganisms. The level required in the diet varies and levels in plants can vary significantly due to environmental parameters. Barry (1985) demonstrated that condensed tannin levels in lotus are dependent upon fertility of the soil. Barry (1985) demonstrated conclusively that high concentrations of CT prevent maximum expression of live weight gain in young sheep. This result was predominately mediated through a depression in feed intake. These results are in contrast to those obtained with growing sheep grazing the same cultivar in high fertility soils. Under these conditions Lotus pendunculatus contains $20 \mathrm{~g} / \mathrm{kg}$ dry matter (DM) of CT and it is believed that at this concentration a beneficial effect is seen. Polyethylene glycol (PEG) increases feed

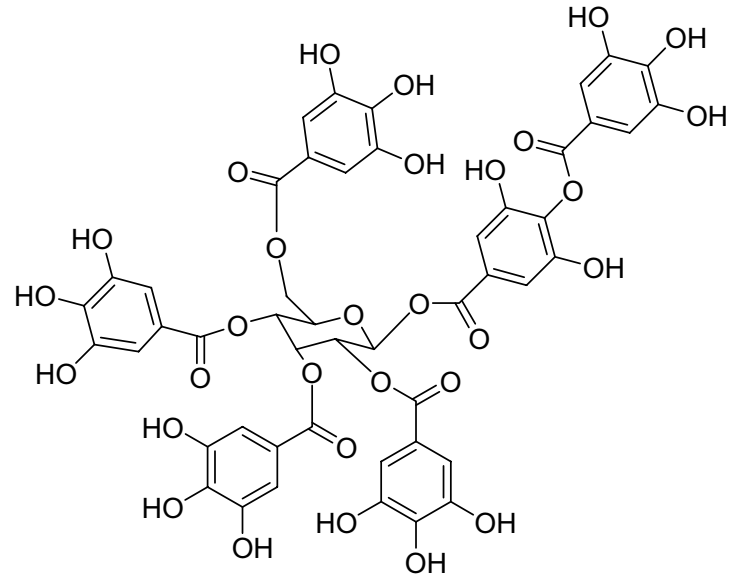

1. Gallotannin

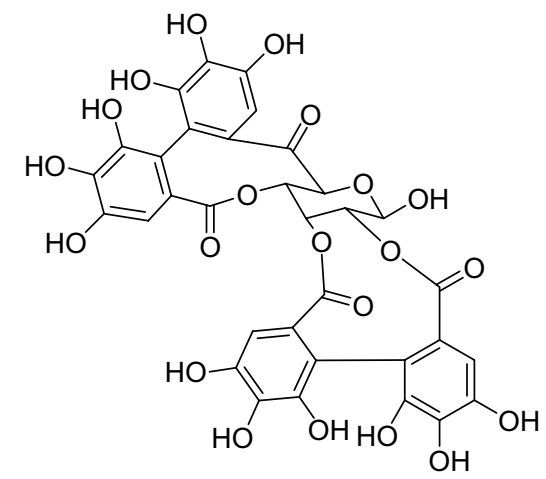

2. Ellagitannin<smiles>Oc1cc(O)c2c(c1)OC(c1ccc(O)c(O)c1)C(O)C2c1c(O)cc(O)c2c1OC(c1ccc(O)c(O)c1)C(O)C2c1c(O)cc(O)c2c1OC(c1ccc(O)c(O)c1)C(O)C2</smiles>

3. Proanthocyanidins (condensed tannins)

Fig. 2. Examples of tannin chemical structures. 
intake when sheep are fed CT containing diets. PEG prevents binding of $\mathrm{CT}$ to protein so this suggests that the effect may be due to polyphenolic plant metabolites.

Dietary CT per se can be considered as nutritionally deleterious and a net benefit only occurs with ruminants given fresh forage diets when the tannins react with forage proteins and reduce their solubility. The ideal amount of CT in a ruminants' diet would therefore be the minimum amount of CT necessary to render the plant protein insoluble, $(20-40 \mathrm{~g} / \mathrm{kg} \mathrm{DM}$ is believed to be the ideal CT concentration in Lotus sp. (Barry, 1985)).

Tannins are not the only plant metabolites that are implemented in changing dry matter intake (DMI). DMI was increased for steers fed supplemental betaine compared to control steers resulting in increased fat deposition in the betaine-supplemented group (Loest et al., 2002).

Feed intake can be altered by palatability, as in the case of tannin, but physical properties are also important. Thorns or excessively rough material can effect forage intake, particularly of potentially important leguminous shrubs. Behaviour and feed intake may also be effected by aroma. Estell et al. (1998) demonstrated that terpene volatiles could effect feed intake in sheep. Varying levels of camphor (4) and $\alpha$-pinene (5) (Fig. 3) were implicated in differential use of 'tarbush' by ruminants. Knowledge of specific chemical interactions with feed intake may therefore ultimately lead to mechanisms for altering feeding behaviour.

\subsection{Wool growth}

Wool growth is sensitive to the absorption of protein and overall health of the animal. The presence of condensed tannins in lotus and sainfoin in the diet of sheep may be expected to contribute to increased amino acid absorption and nitrogen retention. A 55 day feeding study carried out in New Zealand suggested that sheep grazing lotus showed improved reproduction and also increased wool production (Min et al., 1999). Analysis of plasma suggests that the effect was due to an increase in essential amino acids, particularly branched chain amino acids. This was achieved without increased voluntary feed intake. Polyethylene glycol (PEG) supplementation negated the benefit of feeding on Lotus, suggesting that the tannin is responsible for the positive results. This may, at least in part, be due to the higher metabolizable energy of Lotus compared to pasture. A similar study carried out over two years under commercial dryland farming conditions

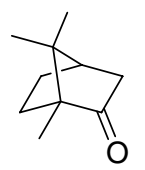

4. Camphor

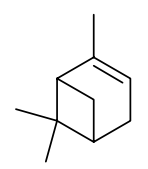

5. $\alpha$-pinene
Fig. 3. Volatile terpenes. showed that such effects were greatest in years with exceptionally dry autumn periods (Ramirez-Restrepo and Barry, 2005; Ramirez-Restrepo et al., 2005).

\subsection{Growth and carcass composition}

Nutritional studies on animal growth have often centred on an understanding of macronutrients (protein, fat, carbohydrate), however, it is becoming apparent that plant bioactives affect not only animal growth but also carcass composition. In meat animals this has significant implications for consumer acceptance. Feed additives of natural origin, namely betaine and conjugated linoleic acid can improve the fat:lean ratio in some circumstances (Sillence, 2004).

Betaine is a naturally occurring amino acid derivative (tri-methyl glycine) found in many plant and invertebrate species. Physiologically, betaine has an important osmoregulatory action and can serve as a methyl group donor via $S$-adenosyl-methionine. When incorporated into pig diets, betaine has been reported to improve growth performance by reducing the maintenance energy requirement of the animal (Schrama et al., 2003; Suster et al., 2004). This occurs through reducing the need for sodium/potassium pumping to maintain cellular osmolarity. In addition, dietary betaine has been reported to increase protein deposition and carcass leanness (Fernandez-Figares et al., 2002; Matthews et al., 2001a,b) and decrease back-fat (Cadogan et al., 1993). Betaine can also improve water holding capacity and reduce drip loss in meat (Dunshea et al., 2005). There have been fewer studies in ruminants, but there is some evidence that dietary betaine can reduce heat stress and improve feed intake and growth performance in beef cattle (M. Mottram, personal communication). Also, dietary betaine can improve the integrity of gut mucosal cells and reduce the severity of some enteric infections in poultry (Matthews and Southern, 2000; Klasing et al., 2002). It is possible that dietary betaine, either as a supplement or from plants naturally high in betaine, may provide a number of benefits to ruminant species.

Saturated fat from red meat in the diets of consumers has been associated with an increased risk of developing coronary heart disease and colorectal cancer. This has resulted in the dietetic recommendation to decrease red meat intake (Eynard and Lopez, 2003). Essential fatty acids such as conjugated linoleic acid (CLA) (6) (Fig. 4) and other polyunsaturated fatty acids (PUFAs) have been demonstrated to have anti-carcinogenic, antithrombogenic and antiatherogenic properties. PUFAs also exhibit antioxidant effects in meat products which may enhance colour and extend shelf life, providing advantages for both retailers and consumers. Antioxidants in the form of selenium, vitamin E (7) (and related tocopherols), flavonols such as quercetin and larger polyphenolics such as tannins, have been demonstrated to have diverse biological effects some of which can be related to the reduction of free radicals. In animal studies high intake of compounds such as 


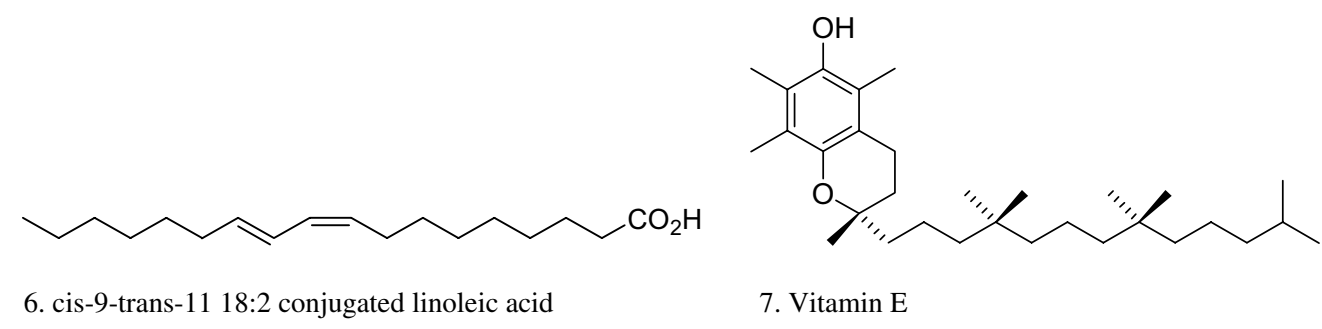

Fig. 4. CLA and Vitamin E.

vitamin $\mathrm{E}$ correlates with reduction of placental retention and mastitis in dairy cattle, but also a greater stability of meat colour (Demeyer et al., 2004).

Conjugated linoleic acid (CLA) is a mixture of positional and geometric isomers of linoleic acid with conjugated double bonds located at positions 7-9, 8-10, 9-11, $10-12$ or $11-13$ on the carbon chain with milk fat a potentially rich source of the cis-9-trans-11 (rumenic acid) and trans-10-cis-12 isomers. There is extensive literature that suggests that the cis-9-trans-11 18:2 CLA isomer has anticancer and other positive health properties (Bauman et al., 2005; Pariza et al., 2001; Parodi, 2002; Whigham et al., 2000) while the trans-10-cis-12 isomer is thought to cause a reduction in lipid deposition in growing animals (de Deckere et al., 1999; Ostrowska et al., 1999, 2003; Dunshea et al., 2002). Rumenic acid is the predominant CLA isomer within ruminant milk and adipose tissue fat constituting approximately $85 \%$ of the total CLA isomers (Bauman et al., 2005). The predominant trans 18:1 fatty acid in ruminant fat is trans-11 18:1 (vaccenic acid) accounting for approximately half of the trans 18:1 isomers (Bauman et al., 2005). Vaccenic acid is also an important precursor of rumenic acid, since humans and other mammals have the capacity to produce CLA from vaccenic acid through the action of delta-9-desaturase in the liver (Griinari et al., 2000). Ostrowska et al. $(1999,2003)$ demonstrated that feeding a mix of CLA to pigs decreases fat deposition by up to $40 \%$ and increases in protein deposition have been reported. Raw materials in the diets of ruminants may have an influence on the fatty acid composition of fat and muscle tissue by both the amount and composition of lipids in each ingredient (Bas and Morand-Fehr, 2000). Pasture is a rich source of PUFA in the diet of ruminants, however, knowledge regarding the fat content and composition of forages available to grazing animals and the subsequent conversion into meat products is limited. The potential exists to produce animal products that are inherently healthier via increased levels of PUFA and CLA when grazed on certain pasture species compared to other pastures or grain feeding (Table 2). Promising data (Table 2) would indicate significant variation in fatty acid composition for different forage species and phenological growth stages.

Temperature has also been suggested as a significant source of variation in PUFA concentrations in milk (Collomb et al., 2002). However, it is more likely that plant spe- cies such as $\mathrm{C}_{3}$ plants are responsible for compositional changes in meat and milk products. The conversion of fats from forage to animal tissues and milk has been noted as being influenced by age, sex, lactation, level of fattening and fatty acid composition and previous dietary fat intake (Bas and Morand-Fehr, 2000; Dewhurst et al., 2006). The potential exists to produce animal products that are inherently healthier via increased levels of PUFA and CLA when grazed on certain pasture species compared to other pastures or grain feeding (Table 2).

Polyunsaturated fatty acids, including CLA, and transvaccenic concentrations are higher in the meat from animals with a high pasture intake than meat from animals fed a high concentrate diet (Aurousseau et al., 2004; Realini et al., 2004). For example, cis/trans-9,11 CLA and total trans$18: 1$ fatty acids were 16 and $62 \mathrm{mg} / \mathrm{g}$ fat in intramuscular fat from lambs fed pasture as compared to 6 and $36 \mathrm{mg} / \mathrm{g}$ fat in muscle from lambs fed concentrate diets (Aurousseau et al., 2004). Also, CLA can be further enhanced through feeding of rumen protected CLA and this offers a potential means of increasing the CLA content of ruminant meat products (Gillis et al., 2004). The opportunities that exist for ruminant meats are to first of all position intramuscular fat as being excellent sources of CLA and polyunsaturated fatty acids and also to develop markets with products that are further enriched through dietary manipulation. Few, if any, studies have investigated the effects of CLA manipulation on immunity in ruminants but dietary supplementation in other species does modulate different aspects of cellular host defence such as mitogen-induced lymphocyte proliferation, lymphocyte cytotoxic activity and macrophage bactericidal activity (Chew et al., 1997) as well as inhibiting prostaglandin E2 synthesis (Belury and Kempa-Steczko, 1997; Liu and Belury, 1998; Bassaganya-Riera et al., 2001). Also, dietary CLA modulates modulates haematological and humoral responses in a dose-dependant manner in pigs (Ostrowska et al., 2004) and it may be possible that increasing ruminal production of CLA production may provide a means to improve animal health.

\subsection{Milk}

Condensed tannin containing forages such as L. corniculatus have been shown to increase milk yield in ewes in the spring and summer. The L. corniculatus spp. contained $44.5 \mathrm{~g} / \mathrm{kg}$ DM CT that is close to the reported limit for a 
Table 2

Variation in fatty acid content of intramuscular fat for animals fed forage and grain based diets

\begin{tabular}{|c|c|c|c|c|c|c|c|}
\hline & Pasture & Species & Supplement & PUFA $\%$ & CLA $\%$ & $\mathrm{SF} \%$ & Comments \\
\hline Velasco et al. (2004) & $\begin{array}{l}15 \% \text { Trifolium spp. } 45 \% \text { Lolium, } \\
\text { Bromus, \& Agrostis sp, } 40 \% \\
\text { Compositae. (Oak-wooded } \\
\text { pasture land) }\end{array}$ & Lambs & Barley or conc & $10.56-13.48 \%$ & & $51-55 \%$ & $\begin{array}{l}\text { Study assessed the influence of weaning and } \\
\text { supplementation type on fatty acid analysis. } \\
\text { Significant difference for weaning and } \mathrm{W} \times \mathrm{F} \\
\text { interaction }\end{array}$ \\
\hline French et al. (2000) & $\begin{array}{l}\text { (Rotationally grazed grassland) } \\
\text { Irish study - assume C } 3 \text { grass }\end{array}$ & Cattle & No & $4.14-5.35 \%$ & $0.37-1.08 \%$ & $44-48 \%$ & $\begin{array}{l}\text { Study assessed the influence of grass, grass silage } \\
\text { or concentrates on fatty acid composition of I.M. } \\
\text { fat of beef steers. Significant difference for } \\
\text { increasing level of grass in the diet on increasing } \\
\text { PUFA and CLA and reducing saturated fat in } \\
\text { muscle tissue }\end{array}$ \\
\hline \multirow[t]{2}{*}{ Rowe et al. (1999) } & $\begin{array}{l}\text { Cynodon dactylon pasture } \mathrm{v} \\
\text { grain }\end{array}$ & & & & & & \\
\hline & Brazilian study & Lambs & No & $5.36-4.74 \%$ & & $55-49 \%$ & $\begin{array}{l}\text { Study assessed the difference between grain fed v } \\
\text { C4 pasture. Significant difference for PUFA and } \\
\text { saturated fats for pasture fed animals }\end{array}$ \\
\hline Gatellier et al. (2005) & $\begin{array}{l}\text { Non descript 'summer' pastures } \\
\text { French study }\end{array}$ & Cattle & No & $5.74-9.18 \%$ & & & $\begin{array}{l}\text { Study assessed steers, cows and heifer carcasses at } \\
\text { an abattoir based upon pasture or conc }+ \text { pasture } \\
\text { classification. Significant difference in PUFA for } \\
\text { 'pasture fed' }\end{array}$ \\
\hline Fraser et al. (2004) & $\begin{array}{l}\text { Lucerne, Red clover and } \\
\text { perennial Ryegrass }\end{array}$ & Lambs & No & & $1.09-1.33 \%$ & & $\begin{array}{l}\text { Study assessed finishing lambs on different } \\
\text { pastures and their subsequent effects on carcass } \\
\text { quality. No sig effects for CLA however significant } \\
\text { difference in PUFA:SF for red clover v rye or } \\
\text { lucerne }\end{array}$ \\
\hline Rhee et al. (2003) & $\begin{array}{l}\text { Non descript rangeland } \mathrm{v} \\
\text { intensively fed grain diet. Broom } \\
\text { weed, klein grass, three awn, } \\
\text { silver, tobosa grass and sideoats }\end{array}$ & Lambs & $\begin{array}{l}\text { Sorghum and } \\
\text { lucerne meal } \\
\text { Whole cotton }\end{array}$ & $4.98-9.33$ & 0 & $41-46 \%$ & $\begin{array}{l}\text { No diff found between treatments but } \\
\text { compounded by feeding oilseeds to all treatment } \\
\text { groups. Demonstrates significant difference } \\
\text { between pasture species for all fats }\end{array}$ \\
\hline \multirow[t]{2}{*}{ Dewhurst et al. (2001) } & Lollium spp. Compared & Lollium sp & No & \multirow{2}{*}{\multicolumn{4}{|c|}{$\begin{array}{l}\text { Significant genetic effects on the level and pattern of concentration of fatty acids in grasses. } \\
\text { Potential to breed high lipid grasses }\end{array}$}} \\
\hline & $\begin{array}{l}\text { L. perenne, L. multiforum, } \\
\text { L. x boucheanum }\end{array}$ & & & & & & \\
\hline \multirow[t]{2}{*}{ Elgersma et al. (2003) } & & Lollium & No & \multirow{2}{*}{\multicolumn{4}{|c|}{$\begin{array}{l}\text { Comparison of the fatty acid composition of fresh and ensiled perennial ryegrass affected by } \\
\text { cultivar and regrowth } \\
\text { Significant difference between fresh and ensiled grass }\end{array}$}} \\
\hline & L. perenne & & & & & & \\
\hline
\end{tabular}

CLA, conjugated linoleic acid; PUFA, poly unsaturated fatty acids; SF, saturated fats. 
beneficial effect from this species. Milk yield of cattle and sheep is a critical factor for survival and growth of the young. There have been reports of increased milk yield with supplementation of nicotinic acid in lactating dairy cows. Caffeine has been demonstrated to increase mammary gland development, increase milk yield and growth rates of the young in mice (Sheffield, 1991) and pigs ( $\mathrm{Li}$ and Hacker, 1995), however, there is no data available for ruminants. As noted above, there is the potential to produce milk that is inherently healthier via increased levels of PUFA and CLA when grazed on certain pasture species compared to other pastures or grain feeding.

\subsection{Reproductive efficiency}

In situ grazing of high condensed tannin containing pastures such as Lotus corniculatus, have been suggested to yield higher reproductive efficiency in sheep compared to animals grazed on grass alone. Ramirez-Restrepo et al. (2005) suggested that the grazing of ewes before mating for up to 42 days on $L$. corniculatus increased ovulation rate of ewes resulting in increased multiple births for ewes that were mated on L. corniculatus. However, greater liveweight and liveweight gain of sheep from the L. corniculatus group could be explained by the higher organic matter digestibility (OMD), dietary organic matter digestibility (DOMD) and metabolizable energy (ME) values for L. corniculatus pasture and not just to higher condensed tannins in the L. corniculatus pasture per se. This is an area where further research would be beneficial. One approach would be to feed a control group of animals PEG in the diets. This would allow researchers to assess whether or not the effect was due to tannin.

\subsection{Defleecing agents}

A number of chemicals have been studied as potential defleecing agents in Merino sheep (Reis et al., 1978; Reis, 1978). Mimosine (8) (Fig. 5) a bioactive compound of Leucaena leucocephala has been demonstrated to be effective in stopping the growth of wool, allowing subsequent manual removal of the fleece, though the compound is also toxic at high levels. L. leucocephala has been the subject of considerable investigation since the fast growing leguminous tree is a source of both human and animal

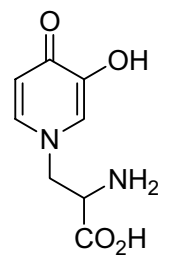

8. Mimosine

Fig. 5. Mimosine - A defleecing agent. nutrition in India. The nutrition value is high; similar to alfalfa forage (D'Mello and Thomas, 1977). Nutritive state of the sheep effects the breakdown of mimosine by the liver. There are also indications that such approaches may be used in Angora goats and sheep (Reis et al., 1999). The toxicity of the compound suggests that such a solution would be of little value in grazing animals since it would be extremely difficult to control the amount of plant material and hence the amount of mimosine that each animal was ingesting. In addition, it is highly likely that the plant's production of mimosine is environment dependent. This would imply that each plant would need to be analysed to ensure that animals were ingesting safe and effective levels. For defleecing using mimosine, a more effective approach would be to administer the compound in a concentrated dose at the correct time of year. Such a dose could be administered as a drench of either concentrated plant extract or purified mimosine. Either approach would require careful assessment of the levels of mimosine in the drench.

\section{Bioactive compounds and their effects on rumen environment}

\subsection{Bacterial populations}

Antibiotic activity is one of the simplest and most important bioactivities to test for and there is a large body of literature reporting on research in this area. Plants have long been a rich source of antibiotics and an extraordinary number of plant metabolites with antibiotic activity have been reported. The majority of plantderived antibiotics tested specifically for ruminants are tested in order to assess the effect on the ruminal flora. The aim is generally related to safety (since ruminants derive much of their nutrition through bacterial gut fermentation, antibiotics can have a deleterious effect on animal health) or to attempts to reduce the Gram positive bacteria that may be associated with less desirable gut metabolism. Recently, it was demonstrated that the forage species Dorycnium rectum contained a range of proanthocyanidins that had varying effects on ruminal bacteria. The plant is unusual compared to other temperate forage legumes since it contains CT of a very high degree of polymerisation. Some species of bacteria were more sensitive to certain structures than others and some, such as $P$. anaerobius, were extremely sensitive to both high and low molecular weight polymers (Sivakumaran et al., 2004).

Tannins are not the only metabolites that effect ruminant flora, and indeed it is likely that many of the nematocides reported in Table 3 will also effect bacterial populations to an extent (though this is largely untested). Essential oils have demonstrated antibiotic activity in vivo and in vitro (Elgayyar et al., 2001; Moreira et al., 2005; Wallace et al., 2002). The oils of anise, oregano 
and cloves have been studied in poultry as an alternative to antibiotics and demonstrate that supplementation with oils may be a natural alternative to promote growth in chickens (Ertas et al., 2005). The use of such natural essential oils is under-explored in ruminants. In addition, this area of research is further limited by a concentration on in vitro studies with few in vivo studies done with grazing animals.

\subsubsection{Foam production/bloat control}

Pasture bloat is a costly disorder, particularly for cattle grazing on high protein improved pastures (Tanner et al., 1995). Frothy bloat is caused by the capture of ruminal gases in a polysaccharide slime layer and causes an inability of the animal to release gas pressure which is formed as a result of ruminal fermentation (Tanner et al., 1995). Proanthocyanidins have been demonstrated to reduce foam production in vitro in a dose dependant manner (Tanner et al., 1995). Similarly, Waghorn and Jones (1989) demonstrated an absence of bloat in cows fed dock (Rumex obtusifolius) at $10 \%$ of dry matter while consuming a lucerne based diet. In addition bloat scores in steers have been reduced by feeding Sainfoin herbage (Onobrychris Viciifolia) at 10-20\% dry matter (McMahon et al., 1999). Although it is possible to co-cultivate a bloat susceptible sward such as lucerne or clover with a CT containing plant such as Sainfoin, Lotus or Dock, consistent intakes of both plants by ruminants must be verified and production traits assessed before full recommendation to producers. A sum-

Table 3

Literature supporting diets for ruminal modification or immunomodulation

\begin{tabular}{|c|c|c|c|c|}
\hline Common name & Botanical name & Active compound & Action & Reference \\
\hline Cinnamon & Cinnamomium spp. & & & \\
\hline \multirow[t]{3}{*}{ Birdsfoot trefoil } & Lotus corniculatus & $\begin{array}{l}\text { Proanthocyanidins/ } \\
\text { condensed tannins }\end{array}$ & Destabilise plant protein foams & $\begin{array}{l}\text { Tanner et al. (1995) } \\
\text { (invitro) }\end{array}$ \\
\hline & Onobrycius viciifolia & $\begin{array}{l}\text { Proanthocyanidins/ } \\
\text { condensed tannins }\end{array}$ & Bloat safe & \\
\hline & Astragular cicer & $\begin{array}{l}\text { Proanthocyanidins/ } \\
\text { condensed tannins }\end{array}$ & Bloat safe & \\
\hline Dock & Rumex obtusifolius & $\begin{array}{l}\text { Proanthocyanidins/ } \\
\text { condensed tannins }\end{array}$ & Bloat safe & Waghorn and Jones (1989) \\
\hline trefoil & Lotus pendunculatus & Condensed tannins & Anti-methanogen & $\begin{array}{l}\text { Tavendale et al. (2005) } \\
\text { (in vitro) }\end{array}$ \\
\hline Lucerne & Medicago sativa & Crude protien/low NDF & Anti-methanogen & \\
\hline Mulga & Acacia aneura & $\begin{array}{l}\text { Proanthocyanidins/ } \\
\text { condensed tannins }\end{array}$ & Protien binding/anti-nutritional & Miller et al. (1997) (in vivo) \\
\hline Yellow wood & Terminalia oblongata & $\begin{array}{l}\text { Hydrolysable tannins - } \\
\text { Gallic acid }\end{array}$ & $\begin{array}{l}\text { Toxic dependant on nutritional } \\
\text { state }\end{array}$ & Murdiati et al. (1991) \\
\hline Yellow wood & Terminalia oblongata & $\begin{array}{l}\text { Hydrolysable tannins } \\
(0.9 \mathrm{~g} / \mathrm{kg} \mathrm{Bwt})\end{array}$ & $\begin{array}{l}\text { Not toxic when fed with } \\
\text { Stylosanthes sp }\end{array}$ & McSweeney et al. (1988) \\
\hline Acacia mearnsii & Acacia mearnsii & Condensed tannins & $\begin{array}{l}\text { Anti-methanogen, decrease } \\
\text { rumen } \mathrm{N} \text { and urea }\end{array}$ & Carulla et al. (2005) \\
\hline Birdsfoot trefoil & Lotus corniculatus & Condensed tannins & $\begin{array}{l}\text { Decreased growth of proteolytic } \\
\text { bacteria }\end{array}$ & Min et al. (2002) (in vitro) \\
\hline Calliandra & Calliandra calothyrsus & Proanthocyanidins & $\begin{array}{l}\text { Decrease purines with } \\
\text { increasing dose }\end{array}$ & Mbugua et al. (2005) \\
\hline \multirow[t]{5}{*}{ Leucaena } & Leucaena leucocephala & Mimosine & Depilatory agent - Goats & Reis et al. (1999) in vivo \\
\hline & Leucaena glauca & Mimosine & Depilatory agent - sheep & $\begin{array}{l}\text { Hegarty et al. (1964) } \\
\text { (in vivo) }\end{array}$ \\
\hline & Quillaja saponaria - Molina & Saponins & Immuno-stimulant & Francis et al. (2005) \\
\hline & Glycyrrhiza radix & Saponins & Anti viral & \\
\hline & Quillaja saponaria & Saponins & $\begin{array}{l}\text { Increase body mass gain in fish, } \\
\text { increased food conversion ratio }\end{array}$ & Francis et al. (2002) \\
\hline Soapberry tree & Sapindus saponara & Saponins & $\begin{array}{l}\text { Decrease rumen protozoa; } \\
\text { decrease rumen } \mathrm{NH}_{4} \text { and } \\
\text { methane conc; decrease } \\
\text { prop:acetate }\end{array}$ & Hess et al. (2003) \\
\hline Birdsfoot trefoil & Lotus corniculatus & Condensed tannins & $\begin{array}{l}\text { Increase reproductive efficiency; } \\
\text { liveweight }\end{array}$ & $\begin{array}{l}\text { Ramirez-Restrepo et al. } \\
(2005)\end{array}$ \\
\hline $\begin{array}{l}\text { Garlic; Cimmamon; Yucca; } \\
\text { Anise; Oregano; } \\
\text { Capsicum; } \\
\text { Cinamaldehyde }\end{array}$ & & Essential oils & $\begin{array}{l}\text { Rumen } \mathrm{pH} \text { dependant }-5.5 \\
\text { significant effects for lower } \\
\text { acetate and higher proprionate } \\
\text { for Ani, ORE, GAR, CAP, } \\
\text { CDH and YUC. Anti- } \\
\text { methanogenic at low pH }\end{array}$ & Cardozo et al. (2005) \\
\hline
\end{tabular}


mary of evidence for plant bioactivity in this area is presented in Table 3.

This is an area, where additional research could have significant industry benefits. Mixed grazing systems or segregated feeding paddocks could reduce the incidence of bloat. For animals such as dairy cattle plant supplements could be added to their diet during milking. Research into additional plants that could be of use in situ and in lots would be a priority. In addition, it is still unclear if tannin is entirely and exclusively responsible for this benefit. Any research in this area would require extensive chemical analysis to ensure that tannin levels and types are qualitatively and quantitatively described across feeding studies.

\subsubsection{Methane production}

Methane is produced as a by-product of the digestive process and represents a loss of feed energy $(2-12 \%)$ from the diet (Pen et al., 2006). Methane is also one of the primary greenhouse gasses and livestock production is the major source of anthropogenic methane (Wood and Knipmeyer, 1998). Both tannins and saponins have received attention for their ability to reduce methane production. Legumes containing condensed tannins decrease gas formation and microbial deamination due to plantprotein interactions. Reducing methane emissions and ruminal protein degradation could result in decreased metabolic energy losses and gaseous nitrogen emissions. Tannins in many plants may reduce ruminal protein breakdown and increase duodenal protein flow when provided at moderate doses (Carulla et al., 2005). However, when given to animals at higher doses they may also adversely affect animal performance. Carulla et al. (2005) supplemented Acacia mearnsii tannins at a level of approximately $0.025 \%$ of the diet DM and significantly reduced methane emissions by $13 \%$. However, the replacement of grass by legumes demonstrated no advantage in reducing methanogenisis. The research in this area raises the interesting possibility of supplemental feeding with feed that incorporates tannin-nutrient complexes as a mechanism to provide high value feed whilst lowering methane production.

Saponins are an important class of plant metabolites that show enormous structural diversity. Essentially they are terpene glycosides the composition of which can vary both in the core terpenoid (sterol derivatives to triterpenes) and also the number, type and substitution pattern of the glycoside residues (Fig. 6). They have numerous biological effects and some can demonstrate highly selective and potent biological activities.

Hess et al. (2003) found that the fruits of $S$. saponaria reduced methane production in an in vitro culture by $11 \%$ in grass-alone and legume supplemented diets. In vitro fermentation experiments using the ruminal fluid of Holstein cows (Pen et al., 2006) demonstrated that Yucca schidigera extract (YSE) decreased methane production whereas Quillaja saponaria extract (QSE) did not. Protozoal numbers decreased in both cases $(56 \%$ with YSE, $41 \%$ with QSE). The authors suggest that the chemical nature of the saponins may be responsible for the differing activities. Yucca saponins have a steroidal (9) nucleus whereas Quillaja saponins have a triterpenoid nucleus (10) (Fig. 6). It would be interesting to see if these in vitro results could be translated to in vivo activity and if the saponins can be administered via plant feed rather than dosing with an extract as in this procedure.

Saponins effect the ruminal flora in other ways. In culture isolates it was demonstrated that YSE stimulates the growth of Prevotella ruminicola and suppresses the growth of Streptococcus bovis. The antimicrobial effect is most pronounced against gram positive bacteria, similar to the action of ionophores. The impact on the complex ruminal bacterial populations is difficult to assess and is also dependant on overall population numbers and variation (Cheeke, 2000).

Other studies have demonstrated the reduction of methane by plant extracts, without identification of the active agents. Broudiscou et al. (2000) investigated the effect of 13 plant extracts in continuous culture. They observed little effect on protozoa numbers but showed that $L$. officinalis (lavender) and $S$. virgaurea promoted the extent of fermentation and that $E$. arvense and $S$. officinalis (sage) had a possible inhibitory effect on methane production. Though the plants were selected for their high flavonoid content, it cannot be assumed the flavonols were responsible for activity. Patra et al. (2006) recently studied the in vitro effect of five plants (Acacia concinna, Terminlaia chebula, Terminalia beleerica, Emblica officinalis and Azadirachta indica) extracted with solvents of varying polarity (water,

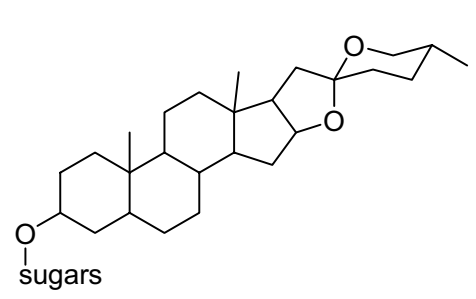

9. Yucca saponin base structure

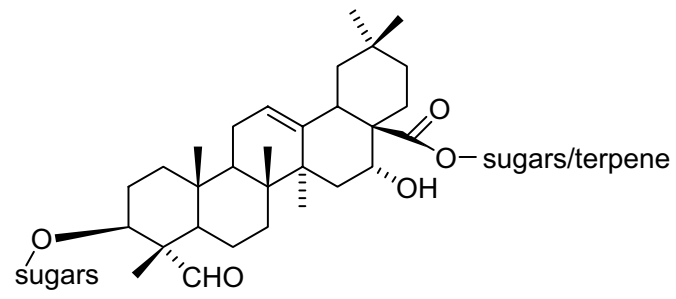

10. Quillaja saponin base structure

Fig. 6. Examples of saponin chemical structures. 
methanol and ethanol). Their results showed T. chebula could be used to reduce methane production. It was interesting to note that these researchers also observed that a decrease in protozoa counts ( $A$. concinna, A. indica and $T$. chebula) does not necessarily mean a decrease in methane production.

A similar study (Sliwinski et al., 2002a) comparing Yucca schidigera extract to Castanea sativa wood extract (CSE; containing hydrolysable tannins and lignan) in in vitro rumen models showed effects on methane production only at very high levels. In vivo studies with fistulated lambs from the same authors concluded that there was a weak potential of YSE and CSE to favourably modify nitrogen turnover in the rumen, in the metabolism of the animal and in manure during storage. Sliwinski et al. (2002b) further concluded that the effects on methanogenesis were inconsistent between in vitro and in vivo data. The authors were using commercial products and suggest the cause for variation between these results and others is the variability in chemical constituents in each extract. This draws attention to studies using plants where levels of bioactives are unknown (Patra et al., 2006) and where these levels are likely to fluctuate with season and location. It also highlights the need for thorough chemical analysis to enable meaningful comparisons across all reported in vitro or in vivo studies.

\section{Nematodes}

Nematodes are a diverse group of organisms with some 30,000 described species. Approximately $50 \%$ of these are marine, $15 \%$ are animal parasites, $10 \%$ are plant parasites and $25 \%$ are free living (Ghisalberti, 2002). Anthelmintic resistance in GI nematodes is an increasing problem, though modern pasture management techniques including pasture rotation, harrowing, regular manure removal, and 'worm and move' programs can be of help in parasite control (Besier and Love, 2003; Nguyena et al., 2005). It has been shown that alternate pastures such as L. corniculatus (birdsfoot trefoil) and Chicorium intybus (chicory) can reduce the nematode load in ruminants. There is question as to whether this effect is due to plant structure effects (i.e. higher grazing so less reinfection in animals through manure ingestion) or by the biological activity of the polyphenolic phytochemicals in the forage (Marley et al., 2005, 2006a,b; Molan et al., 2000; Paolini et al., 2003; RamirezRestrepo and Barry, 2005).

The action of secondary metabolites as antinematodals has been the subject of recent reviews exploring both in vitro and in vivo effects of plant constituents (Ghisalberti, 2002; Githiori et al., 2006). A large number of plants have documented nematocidal activity, though for the majority the bioactives responsible for this activity remain unidentified (Ghisalberti, 2002). This portion of the review includes a more general assessment of bioactives since in many cases a nematocidal plant may be equally effective against both animals and plants. Many of the plants summarised in Table 4 have traditional use. For example, the juice of the marigold flower was used to kill worms in humans since the 1st century AD and is traditionally used in India as an agricultural pest control (Ghisalberti, 2002). It has been suggested that the separation of nematodes into free-living and parasitic is less relevant than how much the species has in common and so an indication for plant bioactives against free-living soil nematodes may also indicate activity for in vivo ruminant control.

The putative bioactives fall into a wide range of chemical classes (Fig. 7). Lipids (fatty acids to complex derivates such as tetrahydrofurans), phenolics (simple stilbenes to complex tannins), alkaloids and terpenes (ranging from essential oils to glycosoylated triterpenes saponins) have all been identified as nematocides. In the case of the simple fatty acids the presence of the acid moiety seems to be important. Lipids such as linoleic and oleic acids, with LD50s of 5-25 ppm are inactive when tested as the methyl ester (Ghisalberti, 2002). Other structural moieties have also been identified as important. For example in the polyenes, such as those obtained from Erigeron philadelphicus (daisy) are most potent when the compounds contain a ketone conjugated to a triple bond, aryl or ester group. In some cases, in vivo activity is not matched by in vitro activity. A metabolite and biosynthetic analogs from the brown alga, Notheia anomala, were potent nematocides with LD50s 1-10 ppm, a level of activity comparable to that of commercially available levamisole and closntel (Capon et al., 1998). However, when tested in vivo in infected sheep there was no evidence of efficacy for the purified metabolites. Almost certainly this is due, in part, to the hydrophobicity of the purified compounds. It is possible that in a different matrix the metabolites would be more bioavailable. Interestingly, the converse may also be true. When the nematocidal effects of $D$. rectum in lambs was studied in New Zealand the effects measured in vitro generally under-estimated effects measured under field conditions (Niezen et al., 2002).

The magnitude of reported bioactivity varies greatly and in some cases it is difficult to assess the level of activity since the specific compound responsible for activity may be unidentified and the plant used in the study may have an unspecified amount of the material. It has already been noted that the structure of tannins is important for their biological activity in other areas and the same is true for their nematocidal properties (Mueller-Harvey et al., 2005). Similarly, the species specific effects of tannins have been noted between sheep and goats whereby the nematode load has been reduced in sheep but not goats (Max et al., 2006). Synergistic effects have been observed and validated in several cases, particularly with respect to essential oils and lipids (Ghisalberti, 2002). The evidence for efficacy is mixed, but in many cases convincing. This is also one area of bioactives chemistry where there have been several 
Table 4

Plants with nematocidal activity

\begin{tabular}{|c|c|c|c|c|c|c|}
\hline Plant cited & $\begin{array}{l}\text { Putative bioactive } \\
\text { (if known) }\end{array}$ & $\begin{array}{l}\text { Chemical class } \\
\text { (if known) }\end{array}$ & $\begin{array}{l}\text { Target organism } \\
\text { (where specified) }\end{array}$ & In vitro & In vivo & Reference \\
\hline Allium sativum (garlic) & Allicin & Thiosulfonates & Haemonchus contortus & $\mathrm{x}$ & Goat & Githiori et al. (2006) \\
\hline Alnnona squamosa & & $\begin{array}{l}\text { Anthraquinone } \\
\text { terpenoids }\end{array}$ & Haemonchus contortus & & Goat & Githiori et al. (2006) \\
\hline Artemisia herva-alba & Santonin & Terpene & Haemonchus contortus & & Goat & Githiori et al. (2006) \\
\hline Calotropis procera & & $\begin{array}{l}\text { Triterpenoids, } \\
\text { anthocyanins, alkaloids }\end{array}$ & Haemonchus contortus & & Sheep & Githiori et al. (2006) \\
\hline Canavalia brasiliensis & & & Haemonchus contortus & & Goat & Githiori et al. (2006) \\
\hline Carica papaya & Benzyl isothiocyanate & Isothiocyanate & Haemonchus contortus & & Goat & Githiori et al. (2006) \\
\hline Chenopodium ambrosioides & Ascaridole & Terpene peroxide & Haemonchus contortus & & Goat & $\begin{array}{l}\text { Githiori et al. (2006), } \\
\text { Ghisalberti (2002) }\end{array}$ \\
\hline Chrysophyllum cainito & & & Haemonchus contortus & & Bovids & Githiori et al. (2006) \\
\hline Hymenaea courbaril & & & Haemonchus contortus & & Goat & (Githiori et al., 2006) \\
\hline Menta spp. & & & Haemonchus contortus & & Goat & (Githiori et al., 2006) \\
\hline Momordica charantia & & & Haemonchus contortus & & Goat & Githiori et al. (2006) \\
\hline Musa acuminate & & & Haemonchus contortus & & Goat & Githiori et al. (2006) \\
\hline Tinospora rumphii & & & Haemonchus contortus & & Goat & Githiori et al. (2006) \\
\hline Butea monosperma & Sterols, palasonin & Terpene & Caenorhabditis elegans & $\mathrm{x}$ & & Githiori et al. (2006) \\
\hline Combretum spp. & Phenantherenes & Aromatics & Caenorhabditis elegans & $\mathrm{x}$ & & Githiori et al. (2006) \\
\hline Cymbogon martini & Geraniol & Terepene & Caenorhabditis elegans & $\mathrm{x}$ & & Githiori et al. (2006) \\
\hline Evodia ruteacarpa ${ }^{1}$ & Atanine $\beta$ & Alkaloid & Caenorhabditis elegans & $\mathrm{x}$ & & Githiori et al. (2006) \\
\hline Ocimum sanctum & Eugenol & Phenolic & Caenorhabditis elegans & $\mathrm{x}$ & & Githiori et al. (2006) \\
\hline Taverniera abyssinica & & $\begin{array}{l}\text { Phytoalexins } \\
\text { (various classes) }\end{array}$ & Caenorhabditis elegans & $\mathrm{x}$ & & Githiori et al. (2006) \\
\hline Terminalia macroptera & & Terpene & Caenorhabditis elegans & $\mathrm{x}$ & & Githiori et al. (2006) \\
\hline Acacia auriculiformis & & & Ascaris lumbricoides & $\mathrm{x}$ & & Githiori et al. (2006) \\
\hline Albizia lebbek & & & Ascaris lumbricoides & $\mathrm{x}$ & & Githiori et al. (2006) \\
\hline Apium graveolens & & & Ascaris lumbricoides & $\mathrm{x}$ & & Githiori et al. (2006) \\
\hline Artemesia santonica & Santonin & Terpene & Ascaris lumbricoides & $\mathrm{x}$ & & Githiori et al. (2006) \\
\hline Cassia obtusifolia & & & Ascaris lumbricoides & $\mathrm{x}$ & & Githiori et al. (2006) \\
\hline Inula helenium & Alantalactone & Terpene & Ascaris lumbricoides & $\mathrm{x}$ & & Githiori et al. (2006) \\
\hline Carica papaya & Benzyl isothiocyanate & Isothiocyanate & Ascaris suum & $\mathrm{x}$ & & Githiori et al. (2006) \\
\hline Mentha cordifolia & $\beta$-Sitosterols, glucosides & Terpene & Ascaris suum & $\mathrm{x}$ & & Githiori et al. (2006) \\
\hline Carica papaya & Benzyl isothiocyanate & Isothiocyanate & Ascaridia galli & $\mathrm{x}$ & & Githiori et al. (2006) \\
\hline Albizia anthelmintica & & & Heligmosomoides polygyrus & $\mathrm{x}$ & & Githiori et al. (2006) \\
\hline Embelia schimperi & Embelin & Hydroxy quinone & Heligmosomoides polygyrus & $\mathrm{x}$ & & Githiori et al. (2006) \\
\hline Alstonia boonei & & & Heligmosomoides polygyrus & $\mathrm{x}$ & & Githiori et al. (2006) \\
\hline Nauclea latifolia & & Akaloids, saponin & Heligmosomoides polygyrus & $\mathrm{x}$ & & Githiori et al. (2006) \\
\hline Ocimum gratissimum & Oleanolic acid & Terpene & Heligmosomoides polygyrus & $\mathrm{x}$ & & Githiori et al. (2006) \\
\hline Piliostigma thonningii & & Tannins, alkaloids & Heligmosomoides polygyrus & $\mathrm{x}$ & & Githiori et al. (2006) \\
\hline Adhatoda vesica & & Alkaloids, glycosides & Mixed GI infections & & Sheep & Githiori et al. (2006) \\
\hline Albizia anthelmintica & & $\begin{array}{l}\text { Sesquiterpene, } \\
\text { kosotoxins }\end{array}$ & Mixed GI infections & & Sheep & Githiori et al. (2006) \\
\hline $\begin{array}{r}\text { Ananas comosus } \\
\text { (pineapple) }\end{array}$ & Bromelain & $\begin{array}{l}\text { Mixture proteolytic } \\
\text { enzymes }\end{array}$ & Mixed GI infections & & $\begin{array}{l}\text { Sheep, } \\
\text { bovid }\end{array}$ & Githiori et al. (2006) \\
\hline
\end{tabular}


Ghisalberti (2002),

Hagenia abyssinica

Hildebrandtia sepalosa

Khaya anthotheca

Khaya senegalensis

Maerua edulis

Myrsine africana

Nauclea latifolia

Solanum aculeastrum

Terminalia glaucescens

Vernonia anthelmintica

Vernonia amygdalina

Medicago sativa (lucerne)

Trifolium pratense (red

$$
\text { clover) }
$$

Trifolium repens (white

$$
\text { clover) }
$$

Lolium perenne (rye grass)

Lotus corniculatus

(birdsfoot trefoil)

Chicorium intybus (chicory)

$\mathrm{CT}$, sequiterpene lactones,

Lolium perenne (rye grass) Tagetes sp (marigolds)

Brassicaceae

Sorghum sudaneselbicolor Manihot esculenta

$$
\text { (cassava) }
$$

Asteraceae e.g. Rudbecia hirta (black eyed susan) Physostigma venenosum (calabar bean)

\section{Dhurrin}

Linamarin etc

Physostigmine
Mixed GI infections

Mixed GI infections

Mixed GI infections

Mixed GI infections

Mixed GI infections

Mixed GI infections

Mixed GI infections

Mixed GI infections

Mixed GI infections

Mixed GI infections

Mixed GI infections

Mixed GI infections

Mixed GI infections

Mixed GI infections

Mixed GI infections

Mixed GI infections

Mixed GI infections

Mixed GI infections

Plant structure, phenolic

Mixed GI

Mixed GI infections

nolic, terpene,

plant structure

\section{Polythienyls}

Isothiocyanate

Glucosinolates

Cyanogenic glycosides

Cyanogenic glycosides

Polyacetylenes

Alkaloid

Sheep

Sheep

Sheep

Sheep

Goat

Sheep

Bovids

Sheep

Sheep

Sheep

Sheep

Bovids

Bovids

Sheep

Bovids

Sheep

Sheep

Sheep

Sheep

Sheep, sheep

Sheep, sheep

and deer

Mixed GI infections

Plant

Sheep

Plant/soil

Githiori et al. (2006)

Githiori et al. (2006)

Githiori et al. (2006)

Githiori et al. (2006)

Githiori et al. (2006)

Githiori et al. (2006)

Githiori et al. (2006)

Githiori et al. (2006)

Githiori et al. (2006)

Githiori et al. (2006)

Githiori et al. (2006)

Githiori et al. (2006)

Githiori et al. (2006)

(Githiori et al., 2006)

Githiori et al. (2006)

Marley et al. (2005)

Marley et al. (2005)

Marley et al. (2005)

Marley et al. (2005)

Marley et al. (2006a,b)

Ramirez-Restrepo,

(2005a,b)

Marley et al. (2006a)

Ramirez-Restrepo and

Barry (2005)

Marley et al. (2006a)

Chitwood (2002)

Chitwood (2002)

Chitwood (2002),

Ghisalberti (2002)

Chitwood (2002)

Chitwood (2002)

Chitwood (2002)

Chitwood (2002) 
Table 4 (continued)

\begin{tabular}{|c|c|c|c|c|c|c|}
\hline Plant cited & $\begin{array}{l}\text { Putative bioactive } \\
\text { (if known) }\end{array}$ & $\begin{array}{l}\text { Chemical class } \\
\text { (if known) }\end{array}$ & $\begin{array}{l}\text { Target organism } \\
\text { (where specified) }\end{array}$ & In vitro & In vivo & Reference \\
\hline Sophora flavescens ${ }^{\mathrm{a}}$ & $\begin{array}{l}\text { Monocrotaline, nmethyl } \\
\text { cytisine, anagyrine, matrine, } \\
\text { sophocarpine, sophoramide }\end{array}$ & Alkaloid & & & & Chitwood (2002) \\
\hline $\begin{array}{l}\text { Decomposing rye } \\
\text { numerous plants }\end{array}$ & Butyric acid & Fatty acids & & & & Chitwood (2002) \\
\hline Iris japonica iris & $\begin{array}{l}\text { 2-undecylenic acid, } \\
\text { linoleic acid }\end{array}$ & Fatty acids & & & & $\begin{array}{l}\text { Chitwood (2002), } \\
\text { Ghisalberti (2002) }\end{array}$ \\
\hline \multirow[t]{2}{*}{ Mucuna (velvet bean) } & 1-Triacontanol & & M. incognnita & $\mathrm{x}$ & & Chitwood (2002) \\
\hline & $\begin{array}{l}\text { Triacontanyl } \\
\text { tetracosanoate }\end{array}$ & & & & & Chitwood (2002) \\
\hline Ocimum basilicum (basil) & $\begin{array}{l}\text { Eugenol, menthol, } \\
\text { cineole, geraniol }\end{array}$ & Terpene oils & H. cajani & & & Chitwood (2002) \\
\hline O. sanctum $^{\mathrm{a}}$ & & & & & & Chitwood (2002) \\
\hline $\begin{array}{l}\text { Mentha piperatum } \\
\text { (peppermint) }\end{array}$ & & & & & & (Chitwood, 2002) \\
\hline $\begin{array}{l}\text { Callistemon lanceolatus } \\
\text { (bottle brush) }\end{array}$ & & & & & & Chitwood (2002) \\
\hline $\begin{array}{l}\text { Eugenia caryophyllata } \\
\text { (clove) }\end{array}$ & & & Broad spectrum & & & Chitwood (2002) \\
\hline $\begin{array}{l}\text { Cymbopogon caesius (kachi } \\
\text { grass) }^{\mathrm{a}}\end{array}$ & & & Sting nematodes & $\mathrm{x}$ & & $\begin{array}{l}\text { Chitwood (2002), } \\
\text { Cox et al. (2006) }\end{array}$ \\
\hline Pinus massoniana & Humulene & Terpene & B. xylophilus & $\mathrm{x}$ & & Chitwood (2002) \\
\hline Daphne odora & Odoracin, odoratrin & Terpene & A. besseyi & $\mathrm{x}$ & & $\begin{array}{l}\text { Chitwood (2002), } \\
\text { Ghisalberti (2002) }\end{array}$ \\
\hline 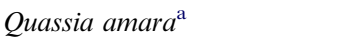 & & Terpene & & $\mathrm{x}$ & & \\
\hline Hannoa undulata & $\begin{array}{l}\text { Chaparrinone, } \\
\text { glaucarubolone and } \\
\text { klaineanone. }\end{array}$ & Terpene & M. incognnita & & & \\
\hline Solanaceae & Tomatine, chaconine & Terpene (glycoalkaloids) & P. redivivus, $M$. incognita & & & \\
\hline $\begin{array}{l}\text { Asparagus adescendens } \\
\text { (shrub) }\end{array}$ & Asparanin $\mathrm{i}$ and $\mathrm{b}$ & Terpene (glycoalkaloids) & & & & \\
\hline Albizia chinensis ${ }^{\mathrm{a}}$ & Albichinin ii & Terpene glycoside & & & & \\
\hline Acacia concinna $^{\mathrm{a}}$ & Sonunin iii & Terpene glycoside & & & & \\
\hline $\begin{array}{l}\text { Acacia auriculiformis (black } \\
\text { wattle) } \mathrm{Oz}\end{array}$ & Acaciaside $\mathrm{a} / \mathrm{b}$ & Terpene glycoside & & & & \\
\hline Dioscorea deltoidea ${ }^{\mathrm{a}}$ & Protodioscin, deltoside & Terpene glycoside & & & & \\
\hline Bacopa monniera herb ${ }^{\mathrm{a}}$ & Jujubogenin glycosides & Terpene glycoside & & & & \\
\hline Lantana camara & $\begin{array}{l}\text { Lantanilic acid, } \\
\text { camaric acid and } \\
\text { oleanolic acid }\end{array}$ & Terpene glycoside & & & & \\
\hline $\begin{array}{l}\text { Ocimum gratissimum (clove } \\
\text { or tree basil) }^{\mathrm{a}}\end{array}$ & Oleanolic acid & Terpene & & & & \\
\hline \multirow[t]{2}{*}{ Cucumis sativus (cucumber) } & Curcurbitacins & Terpene & & $\mathrm{x}$ & Mice & \\
\hline & Pelargonic acid & & & & & Ghisalberti (2002) \\
\hline Helenium sp (asters) roots & Pentayne & Polyacetylenes & & $\mathrm{x}$ & & Ghisalberti (2002) \\
\hline $\begin{array}{l}\text { Carthanmus tinctorius } \\
\text { (safflower) }\end{array}$ & & Polyacetylenes & & $\mathrm{x}$ & & Ghisalberti (2002) \\
\hline Cirsium japonicum (thistle) & & Polyacetylenes & & $\mathrm{x}$ & & Ghisalberti (2002) \\
\hline
\end{tabular}


Ghisalberti (2002) alga)

Annonaceae (large plant

family Inc. pawpaw,

Acetogenins

Ghisalberti (2002)

$$
\text { custard apple) }
$$

Anacardiaceae

(cashew, mango etc)

E. grandis (fresh

Ghisalberti (2002)

eucalyptus leaves)

$$
\text { (Z. liebmannianum) }
$$

Butea frondosa $a^{\mathrm{a}}$

Curcuma longa (turmeric)

e.g. $\beta$-triketone

Sanshool

Palasonin

Tumerone

Rishitin

(potato)

Gossypium hirsutum

$$
\text { (cotton) }
$$

Melia sp. (Meliaceae) Melia azedarach (cape lilac, white cedar)

Phaseolus vulgaris (kidney

$$
\text { bean) }
$$

Solanum incanum Chinese

herb also trad use nigeria

Streblus asper

Piper betle ${ }^{\mathrm{a}}$

\section{Acorus gramineus}

(sweet-flag)

Phaseolus lunatus

(Lima bean)

Pycanthus angolensis

(trad use Cameroon)

Pinus massoniana

Zingiberaceae (turmeric,

cardomon, ginger)

Zingiber officinale

(ginger)

Quisqualis indica

(trad use China)

Asparagus officinalis

\section{Gossypol}

Limonoid 28-deacetyl

sendanin

Glycinoeclepin

\section{Solamargine}

Cardenolides - asperoside

and sterbloside

Chavibetol (betel-phenol

3-hydroxy-4-

methoxyallylbenzene)

Asarone

\section{Coumestrol}

Dihyro-guaiaretic acid

Ligans

Diarlyheptanoids inc.

Curcumin i-iii

Gingerol, shogaol

Potassium quisqualate

Asparagusic acid
Terpene

Terpene

Terpene

Terpene

Terpene

Terpene

Terpene

Terpene

Propenylphenols

Shikimate pathway

(phenolics)

Shikimate pathway

(phenolics)

Shikimate pathway

(phenolics)

Shikimate pathway

(phenolics)

Shikimate pathway

(phenolics)

Shikimate pathway

(phenolics)

Amino acid derived

Amino acid derived
Ghisalberti (2002)

Ghisalberti (2002)

Ghisalberti (2002)

Ghisalberti (2002)

Ghisalberti (2002)

Ghisalberti (2002)

Ghisalberti (2002)

Ghisalberti (2002)

Ghisalberti (2002)

Ghisalberti (2002)

Ghisalberti (2002)

Ghisalberti (2002)

Ghisalberti (2002)

Ghisalberti (2002)

Ghisalberti (2002)

Ghisalberti (2002)

Ghisalberti (2002)

Ghisalberti (2002) (continued on next page) 


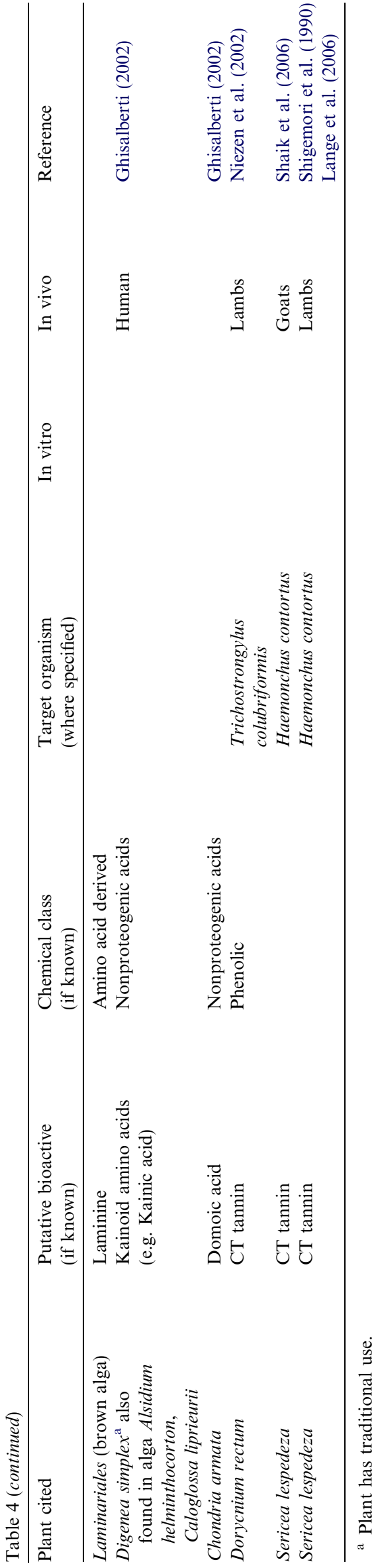

studies on ruminants. A summary of these observations is presented in Table 4.

\section{Potential delivery mechanisms of bioactive compounds to animals}

The potential delivery mechanisms range from a purified plant bioactive (in a capsule or injectable form) to in situ grazing on plants in the paddock. In between these extremes are options such as:

- Drenching with partially purified and concentrated plant extract

- Drenching with crude plant extract

- Incorporation of processed crude plant material or extract into feed pellets or solution

- Application of fresh plant material to the paddock/feed lot

- Application of partially processed plant material to the paddock/feed lot, e.g., plant meal

- Application of preserved plant material to paddock/feed lot e.g. hay, dried material

- Growth of plants in the field for browsing.

The most appropriate delivery method is impossible to predict a priori. The best delivery option will depend on compound stability, potency, bioavailability and safety. Economics of delivery will also be of key importance.

The nature of delivery is also dependent on the type of plant the bioactives are sourced from. For example, there is evidence that bioactives from agricultural waste streams such as citrus waste and chickpea hulls, contain several classes of bioactive compounds including essential oils, tannins, saponins and polyphenolics. It would not be possible to provide the majority of these for in situ foraging but the material could almost certainly be applied to the paddock in a number of ways including as preserved plant material. There is also the potential that the compounds would be suitable for purification and use as a drench.

In terms of regulations, interpretation of the data presented in Section 6, indicates that any product, regardless of what it is will need to be thoroughly tested before any therapeutic statement could be made.

\section{Safety and environmental considerations}

The anti-nutritional activity of tannins is well documented but the potential negative effect of many substances has not been investigated in any detail. Before the introduction of any new feed, in-field toxicity and nutritional effects must be evaluated. The outcomes of such studies may also suggest the best way to deploy the bioactive containing material. For example, if in situ feeding of the plant proves 


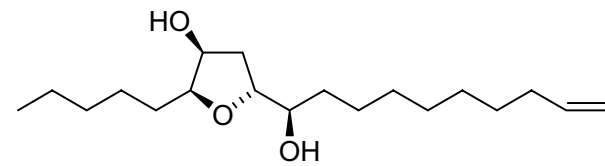

11. tetrahydrofuran from $N$. anomola<smiles>COc1c(CC=C(C)C)c(=O)[nH]c2ccccc12</smiles>

13. atanine from Evodia ruteacarpa

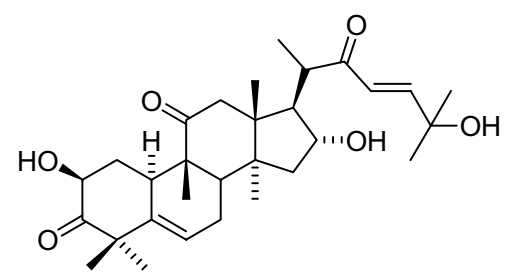

15. curcurbitacin from Cucumis sativus (cucumber)

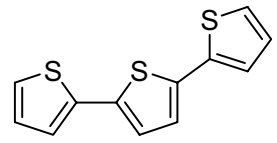

17. $\alpha$-tertthienyl from Marigolds

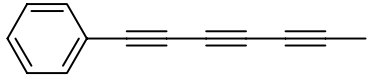

18. polyacetylene

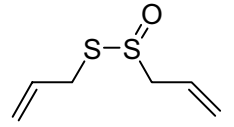

12. allicin from garlic<smiles>CCCCCCCCCCCC1=C(O)C(=O)C=C(O)C1=O</smiles>

14. embelin from Embelia schimperi

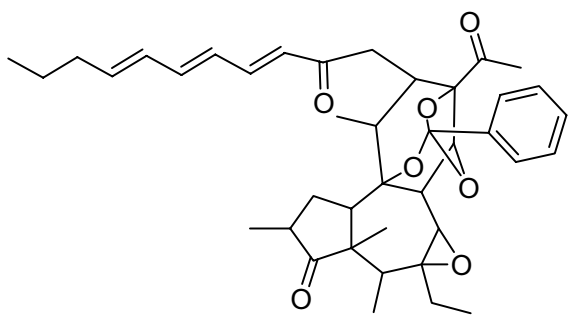

16. odoratrin from Daphne odora

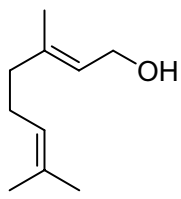

19. geraniol

Fig. 7. Examples of nematocides from plants.

to be detrimental, the plant may still be of use for supplemental feeding where the appropriate dose is more easily monitored. The plant may be provided fresh or dried, as hay or pellets.

Another important consideration is the environmental risk of establishing the use of non-native plants. The plant L. leucocephala, that produces the compound mimosine, mentioned earlier for defleecing, has noxious weed status in several countries. A risk assessment of L. leucocephala for Australia was prepared by Pacific Island Ecosystems at Risk (PIER) and a recommendation to reject the plant for import was made (Global Invasive Species Database, 2006). By contrast the forage plant Sericea lespedeza has been considered as a potential forage crop in Australia (Australian New Crops, 2001) though it is a designated noxious weed in several states of the USA (Kansas State Research, 2005).

\section{Social drivers for the replacement of antibiotics in animal feed}

Human health and safety concerns are ultimately behind the push to reduce the use of antibiotics in animal production. There is increasing public concern regarding the use of pharmaceuticals in the animal industry. Much of this has been as a result of the emergence of drug resistance. A particular area of criticism has been in the use of antibiotics as growth promoters and the associated risk of developing antibiotic resistance in human pathogens, though there is still considerable debate about the science behind these concerns (Barton, 2000). This is not a new issue and in 1969, the Swann report resulted in the withdrawal of $\beta$-lactams from feed in the UK (Ruddock, 2000).

The regulatory push to reduce the level of antibiotic use in animals is strongest in the European Union with legislation to remove antibiotics in animal feed in effect as of January 2006. In the United States there has been less regulation but there has been a reduction in antibiotic use in animal feed through a number of mechanisms.

Lobby groups have had a significant impact and one of the most active in this area in the USA is "Keep Antibiotics Working". The organization describe themselves as "a coalition of health, consumer, agricultural, environmental, humane and other advocacy groups with more than nine million members dedicated to eliminating a major cause of antibiotic resistance: the inappropriate use of antibiotics in food animals". The group lobbies regulators (FDA), law makers (federal government), medical bodies and animal producers (KAW, 2006). 
In 2003, the World Health Organization (WHO) released a report finding that the use of antibiotics in animal feeds could be reduced without serious implications and encouraged countries to follow Denmark's example. Denmark stopped the use of antibiotics in feed in 1999. The report added credence to WHO's long standing view that the use of drugs in healthy animals should be curtailed (Grady, 2003).

As public concern is raised by NGOs large companies such as McDonalds have taken notice. In 2003, McDonald's Corporation announced plans that called for its suppliers worldwide to phase-out animal growth promotion antibiotics that are used in human medicine. The company released a "Global Policy on Antibiotics" that defined a set of standards for McDonald's direct meat suppliers. In a press release from the company antibiotic resistance and the associated social issues were defined as being behind the move, "McDonald's is asking producers that supply over 2.5 billion pounds of chicken, beef and pork annually to take actions that will ultimately help protect public health" (McDonalds Corporation, 2003).

The company's purchasing power has influenced their suppliers. By 2005, all of the chicken meat suppliers with direct relationships with the company had eliminated the use of human antibiotics as growth promoters. Tyson Foods, Perdue Farms and Foster Farms, which combined produce a third of the chickens consumed by Americans, acknowledged that they had voluntarily taken most or all of the antibiotics out of what they feed healthy chickens (Burros, 2005).

Other major purchasers, Wendy's, Dairy Queen and Burger King, have adopted similar strategies towards sourcing their products.

This is not to say regulatory action is unimportant in the USA. In July 2005, the Food and Drug Administration (FDA) banned the use of the antibiotic Baytril in poultry because of concerns that it could lead to antibiotic-resistant infections in people (Associated Press, 2005). In May 2006, the US House of Representatives passed an amendment to allocate US \$1 million to the Food and Drug Administration's Center for Veterinary Medicine. The money will be used to assure the safety of animal drugs with respect to antibiotic resistance.

In Australia, the increasing general concern led to the formation of JETACAR - Joint Expert Advisory Committee on Antibiotic Resistance. This group reported in 1999 that there was evidence for the emergence of antibiotic resistant bacteria through agricultural practice. The report made several recommendations including the establishment of a surveillance system to monitor the emergence of resistant bacteria. As a result, a pilot surveillance program for antimicrobial resistance was set up for 2003-2004. The program was supported by the Department of Agriculture, Fisheries and Forestry (DAFF) and focused on livestock species where antimicrobials are used in feed or water.

A National Health and Medical Research Council (NHMRC) Expert Advisory Group on Antibiotic Resis- tance (EAGAR) was established to provide continuing scientific and technical advice on antibiotic resistance and related matters.

Given the strong regulatory environment of the EU, and the increasing moves of the USA to reduce the use of antibiotics in animal feed, it seems highly likely that such restrictions will eventually be seen in Australia.

\section{Regulatory frameworks}

Animal feed is subject to regulation in many countries including the United States, the European Union and Australia.

\subsection{USA}

In the USA, animal feed is regulated by the Center for Veterinary Medicine (CVM). CVM is a section of the Food and Drug Administration (FDA) which in turn is part of the US Department of Health and Human Services. CVM is responsible for ensuring animal feed is safe and appropriately labeled. This applies to dietary supplements, such as vitamins and minerals, and any other added materials.

In 1994, Congress passed the Dietary Supplement Health and Education Act (DSHEA). DSHEA created a new category of substances with changes in the associated regulatory framework. The main effect was to remove some ingredients from regulation as food additives which required pre-market approval. This created an increase in the number of animal feed products sold with additives for health benefits (generally as a flow on from those used in human products). In 1996, CMV determined that this act did not apply to animal feed and this has been tested successfully in court. This means even if a substance is marketed as a dietary supplement for humans, the substance still falls into the earlier regulatory framework for animals and must be considered a food, food additives, a new animal drug or have GRAS (generally recognized as safe) status. There are many products on the market in the US which are therefore technically illegal. However, these violations are of low enforcement priority (Grassie, 2002).

CVM works in association with the Association of American Feed Control Officials (AAFCO). AAFCO brings together regulators across the USA and Canada. They offer advice to CVM. Examples of relevance are advice in 2002 and 2003 to remove comfrey and kava, respectively, from animal feeds due to concern about the potential toxicity.

Interestingly, AAFCO, had formed a subcommittee to specifically address the issue of botanicals and herbs in feed. However, the Botanicals and Herbs Committee received no submissions for ingredient definitions. The committee recommended to the AAFCO Board of Directors that it be disbanded (replaced with a single investigator) until such a time as there was more demand (Anon, 2002). 
CVM publish a list of approved food additives and GRAS substances in Title 21, Part 570-584 of the Code of Federal Regulations. Any substance that does not fall into these tables cannot be used without thorough safety testing and pre-market regulatory approval. Included in section 582.10: Spices and other natural seasonings and flavorings, are a large number of herbs, including some that may be of value for animal health, for example marigolds (anthelmintic activity).

These regulations would apply to any stock feed, including that designed to be supplemental to grazing.

\subsection{European union}

In Europe, animal feed is ultimately regulated by the European Commission though it acts on recommendations from European Food Safety Authority (EFSA). EFSA carries out evaluations when regulatory approval is sought. Feed additives are defined as "products used in animal nutrition for purposes of improving the quality of feed and the quality of food from animal origin, or to improve the animals' performance and health, e.g. providing enhanced digestibility of the feed materials".

The regulations are strict and safety assessments must include environmental analysis as well as potential to negatively impact human and animal health. EFSA may also require maximum residue limits (MRLs) and a marketmonitoring plan (EFSA, 2006).

The basic legislation was foreshadowed in the European Commission's white paper on food safety. In 2003, this white paper resulted in a formal regulatory framework (European Parliament and Council Regulation (EC) No 1831/2003). It was this regulation that resulted in the phasing out of antibiotic feed additives from January 2006. It also introduced new provisions regarding labeling and packaging of feed additives.

Authorization must be sought for any additive. Additives are broadly grouped into five categories, see Table 5 .

As for the USA, these regulations would apply to any stock feed, including that designed to be supplemental to grazing.

\subsection{Australia}

In Australia, animal feed is regulated by The Australian Pesticides and Veterinary Medicines Authority (APVMA).

Table 5

Feed additive categories in the EU

\begin{tabular}{|c|c|}
\hline Category & Examples \\
\hline Technological additives & $\begin{array}{l}\text { Preservatives, antioxidants, emulsifiers, } \\
\text { stabilising agents, acidity regulators, silage } \\
\text { additives }\end{array}$ \\
\hline Sensory additives & Flavours, colorants \\
\hline Nutritional additives & Vitamins, minerals, amino acids, trace elements \\
\hline Zootechnical additives & Digestibility enhancers, gut flora stabilizers \\
\hline $\begin{array}{r}\text { Coccidiostats and } \\
\text { histomonostats }\end{array}$ & \\
\hline
\end{tabular}

APVMA is a government authority responsible for the assessment and registration of pesticides and veterinary medicines and until 2003, was known as the National Registration Authority for Agricultural and Veterinary Chemicals (NRA).

In 2001, NRA released guidelines for stock food and stock food additives. If no therapeutic, performance enhancing or productivity claims are made then the feed does not require APVMA registration. Medicated stock feeds also do not require registration as long as the veterinary chemicals they contain are registered and the product is labeled with the appropriate instructions for the additive. There is a schedule outlining what are acceptable functional claims for various accepted feed additives.

APVMA also provide a database of active agents that are approved for use (APVMA, 2006a,b). Herbal medicines and nutraceuticals for animals require registration. In effect, this means that any stock feed, including that designed to be supplemental to grazing, and making functional health claims must be registered.

\section{Current research programs}

There are two large EU programs aimed at developing practical alternatives to antibiotic use in animal feed and replacing the use of synthetic antibiotics in animals (EUReplace, 2006). These are large-scale projects involving 7-10 member countries and are well funded.

\subsection{Project 1: Rumen-up}

This work involved the collection of plants and screening them for various activities.

Progress so far is difficult to gauge however, a recent report highlighted 22 plants identified so far with promising activity (Table 6) (Wallace, 2005). These plants were further investigated for in vivo efficacy and to determine the plant chemical/s responsible for the activity.

\subsection{Project 2: Feed for pig health}

Development of Natural Alternatives to Anti-microbials for The Control of Pig Health and Promotion of Performance. Project Funding: 4 million euro (Cordis, 2006). Phase one of the project involved collection of sufficient quantities of the 500 plants/plant extracts to be tested. Phase two of the project, investigated the potential of the plants/plant extracts in the suppression of infections caused by micro-organisms such as Escherichia coli 0149:K88, Clostridium perfringens, Lawsonia intracellularis and nematodes. Studies to investigate the immune stimulatory effects of the plants/plant extracts on fish were completed. The group have now agreed on a list of plant species that have demonstrated potential. The compounds/plant extracts that have been targeted for further research are detailed 
Table 6

Plant materials identified as potential feed additives in RUMEN-UP

\begin{tabular}{|c|c|c|}
\hline Botanical name & Description of the sample & Potential application \\
\hline Arctostaphylos uva-ursi & Bear-berry; leaves and stem & Proteolysis \\
\hline Bellis perennis & Daisy; whole plant, mainly leaves & Protozoa \\
\hline Carduus pycnocephalus & Italian thistle; mixture of stems, leaves and flowers & Methane \\
\hline Epilobium montanum & Broad leaved willowherb; foliage & Proteolysis \\
\hline Eugenia caryophyllata & Clove; dried embryo seed & Protozoa, methane \\
\hline Gentiana asclepidea & Gentian; leaf and stem & Protozoa \\
\hline Gentiana lutea & Gentian; root & Protozoa \\
\hline Helianthemum canum & Rock-rose; leaves and flowers & Proteolysis \\
\hline Knautia arvensis & Field scabious, all overground & Proteolysis \\
\hline Lactuca sativa & Garden lettuce; whole overground & Acidosis \\
\hline Lonicera japonica & Japanese honeysuckle; leaves, stems and flowers & Protozoa \\
\hline Lonicera japonica (flower) & Extract of flowers & Protozoa \\
\hline B-Myrcene & Essential oil compound & Protozoa \\
\hline Olea europaea & Olive; dried leaves & Protozoa \\
\hline Paeoniae alba radix & White peony; root & Methane \\
\hline Peltiphyllum peltatum & Indian rhubarb; whole overground & Proteolysis \\
\hline Populus tremula & Aspen; leaves and stem & Methane \\
\hline Prunus avium & Wild cherry; mainly leaves and small stems & Methane \\
\hline Rheum nobile & Sikkim rhubarb; leaves and stem & Methane \\
\hline Salix caprea & Goat-willow; mainly leaves and small stems & Methane \\
\hline Symphytum officinale & Comfrey; all over ground plant & Protozoa \\
\hline Urtica dioica & Stinging nettles; whole plant & Acidosis \\
\hline
\end{tabular}

in Table 7. Further work will include in vivo analysis and nutrient retention studies (Feed for Pigs, 2005).

There are numerous other research programs and research organisations that investigate the potential benefits of plant bioactives for ruminants. For example the Institute of Grassland and Environmental Research (IGER) in the UK carries out research aiming to optimise ruminant health. The focus of the research is generally forage based but they also utilise novel technologies, such as metabolomics, to investigate systems. Metabolomics is another of the 'omic' sciences and examines the metabolites of an organism as the down stream result of the interaction between genome and environment. Metabolomics techniques can be employed to investigate animal response to medication or feed (Rochfort, 2005).

Similar to IGER, AgResearch in New Zealand is a diverse organisation but several projects within it are of relevance and are focused on strategies to improve ruminant

Table 7

Plant extracts and natural substances identified by the "Feed for Pigs" program with potential to act as replacements for in-feed antimicrobials

\begin{tabular}{ll}
\hline Substance & Mode of action \\
\hline Bacteria & Probiotic, gut health \\
Inulin & Prebiotic \\
Seaweed extracts & Immune system \\
Garlic & Immune system \\
Sanguinarine & Anti-inflammatory \\
Isofavones & Anti-inflammatory \\
Carob Pulp & Anti-bacterial \\
Nucleotides & Anti-inflammatory \\
Thyme & Anti-oxidant \\
Chlorella & Anti-inflammatory \\
\hline
\end{tabular}

health. This includes the use of plants as replacements for antibiotics. In the 2005 annual report, AgResearch reported a project under the Food \& Health Group aimed to identify and determine the chemical structures of a number of novel plant and bacterial molecules that have dual function against the pathogenic bacteria and parasites that cause coccidiosis and necrotic enteritis; conditions that significantly reduce productivity in the intensive animal industries. Research is also dedicated to the reduction of methane emission by ruminants and has included studies on various pasture species. Also in New Zealand, Tom Barry of Massey University, has made significant contributions towards ruminant nutrition, forage feeding value, and the effect of plant secondary compounds, including condensed tannins, on nutritive value.

In Australia, ruminant nutrition and the potential to utilise plants for animal health benefits are areas of on-going study both in the state-based Departments of Primary Industries (e.g. Investigations into the effect of tannin on dairy cow heath and milk production) and the national research organisation, Commonwealth Science and Industry Research Organisation (CSIRO) (e.g. Browse feeding for health - self medicating sheep).

\section{Conclusion}

The use of plant bioactives for animal health is an area of increasing research importance. Many of the studies in ruminants to date have targeted specific classes of bioactives such as tannins and saponins. The focus of most ruminant research has been on ruminal flora modification for a reduction in methane emission and enhanced growth. The 
manipulation of meat and milk quality, particularly with respect to fatty acid composition, is an active area of research. Feeding or supplementation with different plant materials appears to offer a means to alter the lipid composition in animal products, which may result in human health benefit. There have been several ruminant focused studies investigating the use of plants for nematocides, though the focus has again been on the effects of polyphenolics. However, there are plant bioactives of almost every chemical class that have demonstrated nematocidal or antibacterial activity suggesting that this could be a fertile area for future research. One of the problems in assessing much of the available literature is a lack of chemical analysis for the feeds, despite evidence of structure activity relationships in both tannins and saponins. Additionally, many studies have relied on in vitro analysis via ruminal fermentors. This review suggests that plants may indeed be beneficial for animal health, whilst at the same time, highlights the need for more controlled in vivo research to validate plant bioactivity.

\section{Acknowledgment}

This work was financially supported by the Meat and Livestock Australia Limited (MLA).

\section{References}

Anon., 2002. FDA Veterinarian, March/April 2002, vol. XVII, No. II. APVMA, 2006a. PUBCRIS Registered Product Search Engine. $<$ http:// services.apvma.gov.au/PubcrisWebClient/welcome.do;jsessionid=FYtJy1wNQ1LR1JZG6JH1ZRj7C6xWn0W8j1jppvtzNjWh56H Gf61Q!$804521097>$ (accessed 00.08.06).

APVMA, 2006b. <http://www.apvma.gov.au/actives/subpage_actives. shtml $>$ (accessed 00.03.07).

Associated Press, 2005. Citing Human Threat, US Bans a Poultry Drug. Associated Press, Washington, July 29, 2005.

Aurousseau, B., Bauchart, D., Calichon, E., Micol, D., Priolo, A., 2004. Effect of grass or concentrate feeding systems and rate of growth on triglyceride and phospholipid and their fatty acids in the $M$. longissimus thoracis of lambs. Meat Sci. 66, 531-541.

Australian New Crops, 2001. Lespedeza cuneata. <http://www.newcrops.uq.edu.au/listing/lespedezacuneata.htm $>$ (accessed 00.08.06).

Barry, T.N., 1985. The role of condensed tannins in the nutritional value of Lotus pendunculatus for sheep. 3. Rates of body and wool growth. Br. J. Nutr. 54, 211-217.

Barton, M.D., 2000. Antibiotic use in animal feed and its impact on human health. Nutr. Res. Rev. 13, 279-299.

Bas, P., Morand-Fehr, P., 2000. Effect of nutritional: factors on fatty acid composition of lamb fat deposits. Livest. Prod. Sci. 64, 61-79.

Bassaganya-Riera, J., Hontecillas-Magarzo, R., Bregendahl, K., Wannemuehler, M.J., Zimmerman, D.R., 2001. Effects of dietary conjugated linoleic acid in nursery pigs of dirty and clean environments on growth, empty body composition, and immune competence. J. Anim. Sci. 79, 714-721.

Bauman, D.E., Lock, A.L., Corl, B.A., Ip, C., Salter, A.M., Parodi, P.W., 2005. Milk fatty acids and human health: potential role of conjugated linoleic acid and trans fatty acids. In: Sejrsen, K., Hvelplund, T., Nielson, M.O. (Eds.), Ruminant Physiology: Digestion, Metabolism and Impact of Nutrition on Gene Expression, Immunology and Stress.
Wageningen Academic Publishers, Wageningen, The Netherlands, pp. 523-555.

Belury, M.A., Kempa-Steczko, A., 1997. Conjugated linoleic acid modulates hepatic lipid composition in mice. Lipids 32, 199-204.

Besier, R.B., Love, S.C.J., 2003. Anthelmintic resistance in sheep nematodes in Australia: the need for new approaches. Aust. J. Exp. Agric. 43, 1383-1391.

Broudiscou, L.P., Papon, Y., Broudiscou, A.F., 2000. Effects of dry plant extracts on fermentation and methanogenesis in continuous culture of rumen microbes. Anim. Feed Sci. Technol. 87, 263-277.

Burros, M., 2005. "McDonald's Takes Steps on Its Antibiotics Promise" in the New York Times, January 12, 2005. <http://www.nytimes.com/ 2005/01/12/dining/

12MCDO.html?ei $=5070 \& e n=3 a 3 d 082255598302 \& \mathrm{ex}=1159329600 \&-$ pagewanted $=$ print\&position $=>($ accessed 00.08 .06$)$.

Cadogan, D.J., Campbell, R.G., Harrison, D., Edwards, A.C., 1993. The effects of betaine on the growth performance and carcass characteristics of female pigs. In: Batterham, E.S. (Ed.), In: Manipulating Pig Production, vol. IV. Australasian Pig Science Association, Werribee, Australia, p. 219.

Capon, R.J., Barrow, R.A., Rochfort, S.J., Jobling, M., Skeene, C., Lacey, E., Gill, J.H., Friedel, T., Wadsworth, D., 1998. Marine nematocides: tetrahydrofurans from a southern Australian brown alga, Notheia anomala. Tetradedron 54, 2227-2242.

Cardozo, P.W., Calsamiglia, S., Ferret, A., Kamel, C., 2005. Screening for the effects of natural plant extracts at different $\mathrm{pH}$ on in vitro rumen microbial fermentation of a high-concentrate diet for beef cattle. J. Anim. Sci. 83, 2572-2579.

Carulla, J.E., Kreuzer, M., Machmuller, A., Hess, H.D., 2005. Supplementation of Acacia mearnsii tannins decreases methanogenesis and urinary nitrogen in forage-fed sheep. Aust. J. Agric. Res. 56, 961-970.

Cheeke, P.R., 2000. Actual and potential application of Yucca schidigera and Quillaja saponaria saponins in human and animal nutrition. Proc. Am. Soc. Anim. Sci., 1999. Available at: <http://www.asas.org/ symposia/9899proc/0909.pdf $>$ (accessed 00.01.07).

Chew, B.P., Wong, T.S., Shultz, T.D., Magnuson, N.S., 1997. Effects of conjugated dienoic derivatives of linoleic acid and beta-carotene in modulating lymphocyte and macrophage function. Anticancer Res. 17, 1099-1106.

Chitwood, D.J., 2002. Phytochemical based strategies for nematode control. Ann. Rev. Phytopathol. 40, 221-249.

Collomb, M., Butikofer, U., Sieber, R., Jeangros, B., Bosset, J., 2002. Composition of fatty acids in cows milk produced in the lowlands, mountains and highlands of Switzerland using high-resolution gas chromatography. Int. Dairy J. 12, 649-659.

Cordis, 2006. $<$ http://cordis.europa.eu/search/index.cfm?fuseaction $=$ proj. simpledocument\&PJ_RCN $=7517929 \& C F I D=10445816 \& C F T O K E N$ $=10598571>($ accessed 00.08.06).

Cox, C.J., McCarty, L.B., Toler, J.E., Lewis, S.A., Martin, S.B., 2006. Suppressing sting nematodes with Brassica sp., poinsettia, and spotted spurge extracts. Agron. J. 98, 962-967.

De Deckere, E.A., van Amelsvoort, J.M., McNeill, G.P., Jones, P., 1999. Effects of conjugated linoleic acid (CLA) isomers on lipid levels and peroxisome proliferation in the hamster. Br. J. Nutr. 82, 309-317.

Demeyer, D., Raes, K., Fievez, V., De Smet, S., 2004. Radicals and antioxidants in relation to human and animal health: a case for functional feeding. Commun. Appl. Biol. Sci. Ghent University 69, 7591.

Dewhurst, R.J., Scollan, N.D., Youell, S.J., Tweed, K.S., Humphreys, M.O., 2001. Influence of species, cutting date and cutting interval on the fatty acid composition of grasses. Grass Forage Sci. 56, 68-74.

Dewhurst, R.J., Shingfield, K.J., Lee, M.R.F., Scollan, N.D., 2006. Increasing the concentrations of beneficial polyunsaturated fatty acids in milk produced by dairy cows in high-forage systems. Anim. Feed Sci. Technol. 131, 168-206.

D’Mello, J.P.F., Thomas, D., 1977. Animal feed. In: Rushkin, F.R. (Ed.), Leucaena: Promising Forage and Tree Crops for the Tropics. National Academy of Sciences, Washington, DC, pp. 30-32. 
Dunshea, F.R., Ostrowska, E., Luxford, B., Smits, R.J., Campbell, R.G., D'Souza, D.N., Mullan, B.P., 2002. Dietary conjugated linoleic acid can decrease backfat in pigs housed under commercial conditions. Asian Austral. J. Anim. Sci. 15, 1011-1017.

Dunshea, F.R., D'Souza, D.N., Pethick, D.W., Harper, G.S., Warner, R.D., 2005. Effects of dietary factors and other metabolic modifiers on quality and nutritional value of meat. Meat Sci. 71, 8-38.

EFSA., 2006. <http://ec.europa.eu/food/food/animalnutrition/feedadditives/index_en.htm $>$ (accessed 00.08.06).

Elgayyar, M., Draughon, F.A., Golden, D.A., Mount, J.A., 2001. Antimicrobial activity of essential oils from plants against selected pathogenic and saprophytic microorganisms. J. Food Prot. 64 (7), 1019-1024

Elgersma, A., Ellen, G., Van der Horst, H., Muuse, B.G., Boer, H., Tamminga, S., 2003. Comparison of the fatty acid composition of fresh and ensiled perennial ryegrass (Lolium Perenne L.) affected by cultivar and regrowth interval. Anim. Feed Sci. Technol. 108, 191-205.

Ertas, O.N., Ciftci, M., Dalkilic, B., Simsek, U.G., 2005. The effect of an essential oil mix derived from oregano, clove and anise on broiler performance. Int. J. Poultry Sci. 4 (11), 879-884.

Estell, R.E., Fredrickson, E.L., Tellez, M.R., Havstad, K.M., Shupe, W.L., Anderson, D.M., Remmenga, M.D., 1998. Effects of volatile compounds on consumption of alfalfa pellets by sheep. J. Anim. Sci. 76, 228-233.

EU-replace, 2006. <http://www.replace-eu.com/> (accessed 00.08.06).

European Parliament and Council Regulation (EC) No1831/2003, 2006. $<$ http://ec.europa.eu/food/food/animalnutrition/feedadditives/legisl en.print.htm $>$ (accessed 00.08.06).

Eynard, A.R., Lopez, C.B., 2003. Conjugated linoleic acid (CLA) versus saturated fats/cholesterol: their proportion in fatty and lean meats may affect the risk of developing colon cancer. Lipids Health Dis. 2, 1-6.

Feed for Pigs, 2005. <http://www.feedforpighealth.org/public/press/17oct 2005.pdf $>$ (accessed 00.09.06).

Fernandez-Figares, I., Wray-Cahen, D., Steele, N.C., Campbell, R.G., Hall, D.D., Virtanen, E., 2002. Effect of dietary betaine on nutrient utilization and partitioning in the young growing feed restricted pig. J. Anim. Sci. 80, 421-428.

Francis, G., Makkar, H.P.S., Becker, K., 2002. Dietary supplementation with a Quillaja saponin mixture improves growth performance and metabolic efficiency in common carp (Cyprinus carpio L.). Aquaculture 203 (3-4), 311-320.

Francis, G., Makkar, H.P.S., Becker, K., 2005. Quillaja saponins - a natural growth promoter for fish. Anim. Feed Sci. Technol. 121 (1-2), 147-157.

Fraser, M.D., Speijers, M.H.N., Theobald, V.J., Fychan, R., Jones, R., 2004. Production performance and meat quality of grazing lambs finished on red clover, Lucerne or perennial ryegrass swards. Grass Forage Sci. 59, 345-356.

French, P., Stanton, C., Lawless, F., O'riordan, E.G., Manaham, F.J., Caffrey, P.J., Moloney, A.P., 2000. Fatty acid composition, including conjugated linoleic acid, of intramuscular fat from steers offered grazed grass, grass silage, or concentrate-based diets. J. Anim. Sci. 78, 2849 2855.

Gatellier, P., Mercier, Y., Juin, H., Renerre, M., 2005. Effect of finishing mode (pasture- or mixed diet) on lipid composition, colour stability and lipid oxidation in meat from Charolais cattle. Meat Sci. 69, 175186.

Ghisalberti, E.L., 2002. Secondary metabolites with antinematodal activity. In: Atta-ur-Rahman (Ed.), . In: Studies in Natural Products Chemistry, vol. 26. Elsevier Science BV, pp. 425-506.

Gillis, M.H., Duckett, S.K., Sackmann, J.R., Realini, C.E., Keisler, D.H., Pringle, T.D., 2004. Effects of supplemental rumen-protected conjugated linoleic acid or linoleic acid on feedlot performance, carcass quality, and leptin concentrations in beef cattle. J. Anim. Sci. 82, 851859.

Githiori, J.B., Athanasiadou, S., Thamsborg, S.M., 2006. Use of plants in novel approaches for control of gastrointestinal helminthes in livestock with emphasis on small ruminants. Vet. Parasitol. 139, 308-320.
Global Invasive Species Database, 2006. Leucaena leucocephala (tree). $<$ http://www.issg.org/database/species/ecology.asp?si=23\&fr $=1 \&$ sts $=>$ (accessed 00.08.06).

Grady, D., 2003. W.H.O. Finds use of antibiotics in animal feed can be reduced Published: August 14, 2003, in the New York Times. $(<\mathrm{http}: / /$ query.nytimes.com/gst/fullpage.html?sec $=$ health\&res $=9 \mathrm{E} 05 \mathrm{E} 4 \mathrm{D} 81 \mathrm{~F} 3-$ 1F937A2575BC0A9659C8B63>) (accessed 00.09.06).

Grassie, L.A., 2002. Update on animal dietary supplements. FDA Veter. Newslett. XVIII (III).

Greathead, H., 2003. Plants and plant extracts for improving animal productivity. Proc. Nutr. Soc. 62, 279-290.

Griinari, J.M., Corl, B.A., Lacy, S.H., Chouinard, P.Y., Nurmela, K.V., Bauman, D.E., 2000. Conjugated linoleic acid is synthesized endogenously in lactating dairy cows by Delta(9)-desaturase. J. Nutr. 130 , 2285-2291.

Hagerman, A.E., Robbins, C.T., Weerasuriya, Y., Wilson, T.C., McArthur, C., 1992. Tannin chemistry in relation to digestion. J. Range Manage. 45, 57-62.

Hegarty, M.P., Schinkel, P.G., Court, R.D., 1964. Reaction of sheep to the consumption of Leucaena glauca benth. and to its toxic principle mimosine. Aust. J. Agric. Res. 15, 153-157.

Hess, H.D., Monslave, L.M., Lascano, C.E., Carulla, J.E., Diaz, T.E., Kreuzer, M., 2003. Supplementation of a tropical grass diet with forage legumes and Sapindu saponaria fruits: effects on in vitro ruminal nitrogen turnover and methanogenisis. Aust. J. Agric. Res. 54, 703713.

Kansas State Research and Extention, 2005. Sericea Lespedeza (Lespedeza cuneata) a noxious weed. $<\mathrm{http}: / /$ www.oznet.ksu.edu/sericea/ $>$ (accessed 00.08.06).

KAW, 2006. <http://www.keepantibioticsworking.com/new/index.cfm> (accessed 27.09.06).

Klasing, K.C., Adler, K.L., Remus, J.C., Calvert, C.C., 2002. Dietary betaine increases intraepithelial lymphocytes in the duodenum of coccidia-infected chicks and increases functional properties of phagocytes. J. Nutr. Aug. 132 (8), 2274-2282.

Lange, K.C., Olcott, D.D., Miller, J.E., Mosjidis, J.A., Terrill, T.H., Burke, J.M., Kearney, M.T., 2006. Effect of Sericea, Effect of Sericea lespedeza (Lespedeza cuneata) fed as hay, on natural and experimental Haemonchus contortus infections in lambs. Vet. Parasitol. 141, 273278.

Li, S., Hacker, R.R., 1995. The effect of caffeine on mammary gland development and milk yield in primiparous sows. J. Anim. Sci. 73, 534-540.

Liu, K.L., Belury, M.A., 1998. Conjugated linoleic acid reduces arachidonic acid content and PGE2 synthesis in murine keratinocytes. Cancer Lett. 127, 15-22.

Loest, C.A., Titgemeyer, E.C., Drouillard, J.S., Coetzer, C.M., Hunter, R.D., Bindel, D.J., Lambert, B.D., 2002. Supplemental betaine and peroxide-treated feather meal for finishing cattle. J. Anim. Sci. 80, 2234-2240.

Marley, C.L., Fraser, M.D., Fychan, R., Theobald, V.J., Jones, R., 2005. Effect of forage legumes and anthelmintic treatment on the performance, nutritional status and nematode parasites of grazing lambs. Vet. Parasitol. 131, 267-282.

Marley, C.L., Cook, R., Barrett, J., Keating, E., Lampkin, N.H., 2006a. The effects of birdsfoot trefoil (Lotus corniculatus) and chicory (Cichorium intybus) when compared with perennial ryegrass (Lolium perenne) on ovine gastrointestinal parasite development, survival and migration. Vet. Parasitol. 138, 280-290.

Marley, C.L., Fraser, M.D., Roberts, J.E., Fychan, R., Jones, R., 2006b. Effects of legume forages on ovine gastrointestinal parasite development, migration and survival. Vet. Parasitol. 138, 308-317.

Matthews, J.O., Southern, L.L., 2000. The effect of dietary betaine in Eimeria acervulina - infected chicks. Poult. Sci. 79, 60-65.

Matthews, J.O., Southern, L.L., Bidner, T.D., Persica, M.A., 2001a. Effects of betaine, pen space, and slaughter handling method on growth performance, carcass traits, and pork quality of finishing barrows. J. Anim. Sci. 79, 967-974. 
Matthews, J.O., Southern, L.L., Higbie, A.D., Persica, M.A., Bidner, T.D., 2001b. Effects of betaine on growth, carcass characteristics, pork quality, and plasma metabolites of finishing pigs. J. Anim. Sci. 79, 722 728.

Max, R.A., Kimambo, A.E., Kassuku, A.A., Mtenga, L.A., Buttery, P.J., 2006. Tannins: an environmentally friendly method of controlling intestinal parasites in ruminants in the tropics and subtropics? Proc. Br. Soc. Anim. Sci., 30.

Mbugua, D.M., Pell, A.N., Fox, D.G., Schofield, P., 2005. The effects of proanthocyanidins from Calliandra calothyrsus and the alkaloid sparteine on in vitro fiber digestion. Anim. Feed Sci. Technol 121, 89-107.

McDonald's Corporation, 2003. McDonald's Corporation. <http:// www.csrwire.com/synd/business-ethics/article.cgi/1914.htm> (accessed 00.08.06).

McMahon, L.R., Majak, W., McAllister, T.A., Hall, J.W., Jones, G.A., Popp, J.D., Cheng, K.J., 1999. Effect of sainfoin on in vitro digestion of fresh alfalfa and bloat in steers. Can. J. Anim. Sci. 79, 203-212.

McSweeney, C.S., Kennedy, P.M., John, A., 1988. Effect of ingestion of hydrolysable tannins in Terminalia oblongata on digestion in sheep fed Stylosanthes hamata. Aust. J. Agric. Res. 39, 235-244.

Miller, S.M., Pritchard, D.A., Eady, S.J., Martin, P.R., 1997. Polyethylene glycol is more effective than surfactants to enhance digestion and production in sheep fed mulga (Acacia aneura) under pen and paddock conditions. Aust. J. Agric. Res. 48, 1121-1127.

Min, B.R., McNabb, W.C., Barry, T.N., Kemp, P.D., Waghorn, G.C., McDonald, M.F., 1999. The effect of condensed tannins in Lotus corniculatus upon reproductive efficiency and wool production in sheep during late summer and autumn. J. Agric. Sci. 132, 323334.

Min, B.R., Attwood, G.T., Reilly, K., Sun, W., Peters, J.S., Barry, T.N., McNabb, W.C., 2002. Lotus corniculatus condensed tannins decrease in vivo populations of proteolytic bacteria and affect nitrogen metabolism in the rumen of sheep. Can. J. Microbiol. 48 (10), 911-921.

Molan, A.L., Waghorn, G.C., Min, B.R., McNabb, W.C., 2000. The effect of condensed tannins from seven herbages on Trichostrongylus colubriformis larval migration in vitro. Folia Parasitol. 47, 39-44.

Moreira, M.R., Ponze, A.G., del Valle, C.E., Roura, S.I., 2005. Inhibitory parameters of essential oils to reduce a foodborne pathogen. LWT 38 , $565-570$.

Mueller-Harvey, I., 2006. Unravelling the conundrum of tannins in animal nutrition and health. J. Sci. Food Agric. 86 (13), 2010-2037.

Mueller-Harvey, I., Mlambo, V., Smith, T., 2005. Tannins in animal nutrition and health - implications for temperate and tropical feeds. Proc. Br. Soc. Anim. Sci., 72.

Murdiati, T.B., McSweeney, C.S., Lowry, J.B., 1991. Complexing of toxic hydrolysable tannins of yellow-wood (Terminalia oblongata) and harendong (Clidemia hirta) with reactive substances: an approach to preventing toxicity. J. Appl. Toxicol. 11 (5), 333-338.

Nguyena, T.M., Binh, D.V., Orskov, E.R., 2005. Effect of foliages containing condensed tannins and on gastrointestinal parasites. Anim. Feed Sci. Technol. 121, 77-87.

Niezen, J.H., Waghorn, G.C., Graham, T., Carter, J.L., Leathwick, D.M., 2002. The effect of diet fed to lambs on subsequent development of Trichostrongylus colubriformis larvae in vitro and on pasture. Vet. Parasitol. 105, 269-283.

Ostrowska, E., Muralitharan, M., Cross, R.F., Bauman, D.E., Dunshea, F.R., 1999. Dietary conjugated linoleic acid increases lean and decreases fat deposition in the growing pig. J. Nutr. 129, 2037-2042.

Ostrowska, E., Suster, D., Muralitharan, M., Cross, R.F., Leury, B.J., Bauman, D.E., Dunshea, F.R., 2003. Conjugated linoleic acid decreases fat accretion in pigs, evaluation by dual-energy X-ray absorptiometry. Br. J. Nutr. 89, 219-229.

Ostrowska, E., Knowles, A., Cross, R.F., Muralitharan, M., Bauman, D.E., Dunshea, F.R., 2004. The effect of conjugated linoleic acid on immunological status in the grower pig. Aust. J. Agric. Res. 55, $711-$ 718 .
Paolini, V., Dorchies, P., Hoste, H., 2003. Effects of sainfoin hay on gastrointestinal infection with nematodes in goats. Vet. Res. 152, 600 601.

Pariza, M.W., Park, Y., Cook, M.E., 2001. The biologically active isomers of conjugated linoleic acid. Progr. Lipid Res. 40, 283-298.

Parodi, P.W., 2002. Conjugated linoleic acid. In: Roginski, H., Furquay, J.W., Fox, P.F. (Eds.), Encyclopedia of Dairy Sciences. Elsevier Sciences Ltd., London, UK, pp. 1587-1594.

Patra, A.K., Kamra, D.N., Agarwal, N., 2006. Effect of plant extracts on in vitro methanogenesis, enzyme activities and fermentation of feed in rumen liquor of buffalo. Anim. Feed Sci. Technol. 128, 276-291.

Pen, B., Sar, C., Mwenya, B., Kuwaki, K., Morikawa, R., Takahashi, J., 2006. Effects of Yucca schidigera and Quillaja saponaria extracts on in vitro ruminal fermentation and methane emission. Anim. Feed Sci. Technol. 129, 175-186.

Ramirez-Restrepo, C.A., Barry, T.N., 2005. Alternative temperate forages containing secondary compounds for improving sustainable productivity in grazing ruminants. Anim. Feed Sci. Technol. 120, 179-201.

Ramirez-Restrepo, C.A., Barry, T.N., Lopez-Villalobos, N., Kemp, N., Harvey, T.G., 2005. Use of Lotus corniculatus containing condensed tannins to increase reproductive efficiency in ewes under commercial dryland farming conditions. Anim. Feed Sci. Technol. 121, 23-43.

Realini, C.E., Duckett, S.K., Brito, G.W., Dalla Rizza, M., De Mattos, D., 2004. Effect of pasture vs. concentrate feeding with or without antioxidants on carcass characteristics, fatty acid composition, and quality of Uruguayan beef. Meat Sci. 66, 567-577.

Reis, P.J., 1978. Effectiveness of intravenous and abomasal doses of mimosine for defleecing sheep and effects on subsequent wool growth. Aust. J. Agric. Res. 29, 1043-1055.

Reis, P.J., Tunks, D.A., Downes, A.M., 1978. Mimosine, administered orally and two related compounds as chemical defleecing agents for sheep. Aust. J. Agric. Res. 29, 1065-1075.

Reis, P.J., Puchala, R., Sahlu, T., Goetsch, A.L., 1999. Effects of mimosine and 2,3-dihydroxypyridine on fibre shedding in Angora goats. J. Anim. Sci. 77, 1224-1229.

Rhee, K.S., Lupton, C.J., Ziprin, Y.A., Rhee, K.C., 2003. Carcass traits of rambouillet and Merino $\times$ Rambouillet lambs and fatty acid profiles of muscle and subcutaneous adipose tissues as affected by new sheep production system. Meat Sci. 65, 693-699.

Robbins, C.T., Hagerman, A.E., Austin, P.J., McArthur, C., Hanley, T.A., 1991. Variation in mammalian physiological response to a condensed tannin and its ecological implications. J. Mamm. 72, 480486 .

Rochfort, S., 2005. Metabolomics reviewed: a new "omics" platform technology for systems biology and implications for natural products research. J. Nat. Prod. 68, 1813-1820.

Rowe, A., Macedo, F.A.F., Visentainer, J.V., Souza, N.E., Matsushita, M., 1999. Muscle composition and fatty acid profile in lambs fattened in drylot or pasture. Meat Sci. 51, 283-288.

Ruddock, J.C., 2000. Secondary metabolites as a vital source of animal health products. Special Publication - Royal Soc. Chem. 257, 45-58 (Biodiversity: New leads for the pharmaceutical and agrochemical industries).

Schrama, J.W., Heetkamp, M.J., Simmins, P.H., Gerrits, W.J., 2003. Dietary betaine supplementation affects energy metabolism of pigs. J. Anim. Sci. 81, 1202-1209.

Shaik, S.A., Terrill, T.H., Miller, J.E., Kouakou, B., Kannan, G., Kaplan, R.M., Burke, J.M., Mosjidis, J.A., 2006. Sericea lespedeza hay as a natural deworming agent against gastrointestinal nematode infection in goats. Vet. Parasitol. 139, 150-157.

Sheffield, L.G., 1991. Caffeine administered during pregnancy augments subsequent lactation in mice. J. Anim. Sci. 69, 1128-1132.

Shigemori, H., Sakai, N., Miyoshi, E., Shizuri, Y., Yamamura, S., 1990. Bioactive substances from Lespedeza cuneata L.G. Don and their biological activities. Tetrahedron 46, 383-394.

Sillence, M.N., 2004. Technologies for the control of fat and lean deposition in livestock. Vet. J. 167, 242-257. 
Sivakumaran, S., Molan, A.L., Meagher, L.P., Kolb, B., Foo, L.Y., Lane, G.A., Attwood, G.A., Fraser, K., Tavendale, M., 2004. Variation in antimicrobial action of proanthocyanidins from Dorycnium rectum against rumen bacteria. Phytochemistry 65, 2485-2497.

Sliwinski, B.J., Soliva, C.R., Machmuller, A., Kreuzer, M., 2002a. Efficacy of plant extracts rich in secondary constituents to modify rumen fermentation. Anim. Feed Sci. Technol. 101, 101-114.

Sliwinski, B.J., Kreuzer, M., Wettstein, H.R., Machmuller, A., 2002b. Rumen fermentation and nitrogen balance of lambs fed diets containing plant extracts rich in tannins and saponins, and associated emissions of nitrogen and methane. Arch. Anim. Nutr. 56, 379-392.

Suster, D., Leury, B.J., King, R.H., Mottram, M., Dunshea, F.R., 2004. Interrelationships between porcine somatotropin (pST), betaine, and energy level on body composition and tissue distribution of finisher boars. Aust. J. Agric. Res. 55, 983-990.

Tanner, G.J., Moate, P.J., Davis, L.H., Laby, R.H., Yuguang, L., Larkin, P.J., 1995. Proanthocyanidins (condensed tannin) destabilise plant protein foams in a dose dependant manner. Aust. J. Agric. Res. 46, $1101-1109$.

Tavendale, M.H., Meagher, L.P., Pacheco, D., Walker, N., Attwood, G.T., Sivakumaran, S., 2005. Methane production from in vitro rumen incubations with Lotus pedunculatus and Medicago sativa, and effects of extractable condensed tannin fractions on methanogenesis. Anim. Feed Sci. Technol. 123 (123-124), 403-419.

Velasco, S., Caneque, V., Lauzurica, S., Perez, C., Huidobro, F., 2004. Effect of different feeds on meat quality and fatty acid composition of lambs fattened at pasture. Meat Sci. 66, 457-465.

Waghorn, G.C., Jones, W.T., 1989. Bloat in cattle 46. Potential of dock (Rumex obstusifolius) as an antibloat agent for cattle. NZ. J. Agric. Res. 32, 227-235.

Wallace, R., REPLACE: a European project on plants, their extracts and other natural alternatives to antimicrobials in animal feeds. Euro Surveill 2005;10(3):E050303.5. <http://www.eurosurveillance.org/ew/ 2005/050303.asp\#5>.

Wallace, R.J., McEwan, N.R., McIntosh, F.M., Teferedegne, B., Newbold, C.J., 2002. Natural products as manipulators of rumen fermentation. Asian-Aust. J. Anim. Sci. 15, 1458-1468.

Whigham, L.D., Cook, M.E., Atkinson, R.L., 2000. Conjugated linoleic acid: implications for human health. Pharmacol. Res. 42, 503-510.

Wood, C., Knipmeyer, C.K., 1998. Applied Environmental Science: global climate change and environmental stewardship by ruminant livestock producers. National Council for Agricultural Education, p. 14.

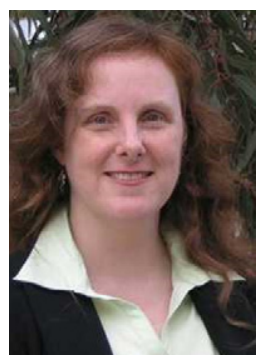

Simone Rochfort completed her $\mathrm{PhD}$ in marine natural products chemistry at the University of Melbourne in 1996. After a postdoctoral fellowship with Dr. Jeffrey Wright, National Research Council of Canada, she returned to Australia to take up a research position with AstraZeneca and Griffith University where she worked the discovery of natural products for human pharmaceuticals. Dr. Rochfort's research in the pharmaceutical and biotech industries continued until 2004 when she joined the Victorian Department of Primary Industries. She is currently employed as a Prin- cipal Research Scientist and applies her natural products research interests to metabolomics and the substantiation of functional foods.

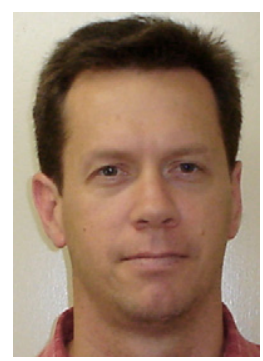

Anthony Parker graduated with a B.App.Sc in animal production from the University of Queensland. He received his Ph.D. in animal physiology from James Cook University in 2005. $\mathrm{He}$ has worked as a ruminant nutritionist and animal production consultant in the dairy, beef and sheep industries in Australia. He is currently employed by Ridley Agriproducts Pty. Ltd. as a product development manager.

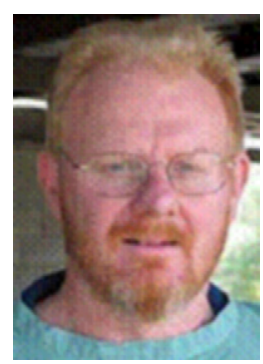

Frank Dunshea received his B.Agric.Sci. (Hons.) and $\mathrm{Ph} . \mathrm{D}$. degrees from La Trobe University in Melbourne Australia in 1983 and 1988, respectively. His Ph.D. research was on fat metabolism in the undernourished and lactating goat, and was directed by Professor Alan Bell. After a postdoctoral fellowship with Professor Dale Bauman at Cornell University he returned to Werribee, Australia to work in governmentfunded research. His research focused around the interactions between human and animal nutrition and the use of domestic animals in nutritional and biomedical research, particularly in the areas of functional foods and bioactives. In 1994, he was the inaugural recipient of the Nutrition Society of Australia Research Award and in 2004 was awarded the Daniel McAlpine Outstanding Achievement Award for Innovation in Agricultural Research for his biomedical and functional foods research. In 2006, He was appointed as the Chair of Agriculture at the University of Melbourne where he continues to work in the area of plant and animal bioactives. 